Jurnal Indonesia Sosial Teknologi: p-ISSN: 2723 - 6609

e-ISSN : 2745-5254

Vol. 2, No. 6 Juni 2021

\title{
PELAPISAN BAJA KARBON JIS S50C MENGGUNAKAN METODE ELEKTROPLATING: VARIASI PELAPISAN NICKEL (Ni) DAN CHROM (Cr) TERHADAP SIFAT FISIK DAN SIFAT KIMIA
}

\author{
Zha Zha Oktaviana Dela Putri, Kardiman dan Rizal Hanfi \\ Universitas Singaperbangsa Karawang \\ Email: zhazha.16-132@student.unsika.ac.id,kardiman@ft.unsika.ac.id, \\ rizal.hanifi@ft.unsika.ac.id
}

\begin{abstract}
Coating is the final part of the production process of a product by giving certain properties to the surface of the workpiece in the hope that the object will experience improvement in its physical properties to reach shape after 6 machining processes and refinement of the workpiece surface. Nickel is iron and cobalt which is often used for rust prevention purposes and to add beauty. The purpose of this study was to seek sem testing, corrosion testing, thickness testing and roughness testing of the JIS S50C Carbon Steel Plating with nickel and chrome electroplating methods carried out at the Mechanical Engineering Laboratory of Sigaperbangsa, Karawang University, while testing and analysis of the results of experimental materials at the Center for Materials and Technical Products. (B4T) Bandung and the Physics Research center at LIPI Serang. This research uses electroplating tools and electrolyte reservoir components, power supply, anode and cathode clamp, heater, aerator, electric grinder, vickers hardness tester, Salt Spray Chamber and optical microsops.
\end{abstract}

Keyword: steel plating; electroplating method, physical properties and chemical properties.

\begin{abstract}
Abstrak
Pelapisan menjadi bagian akhir dari proses produksi dari suatu produk dengan melakukan pemberian sifat tertentu pada suatu permukaan benda kerja dengan mengharapkan benda tersebut akan mengalami perbaikan terhadap sifat fisiknya mencapai bentuk setelah 6 proses pengerjaan mesin serta penghalusan terhadap permukaan benda kerja. Nikel terdapat besi dan kobalt yang sering digunakan untuk tujuan pencegahan karat dan menambah keindahan.Tujuan penelitian ini mencari pengujian sem, pengujian korosi, pengujian ketebalan dan pengujian kekerasar dari Pelapisan Baja Karbon JIS S50C dengan metode electroplating nikel dan krom dilakukan di Laboratorium Teknik Mesin Universitas Sigaperbangsa Karawang, sedangkan pengujian serta analisa hasil eksperimen material di Balai Besar Bahan dan Barang Teknik (B4T) Bandung dan pusat Penelitian Fisika di LIPI Serang. Penelitian ini menggunakan alat electroplating dan komponen bak penampung elektrolit, power supply, penjepit anoda dan katoda, heater, aerator, gerinda listrik, alat pengujur kekerasan vickers, Salt Spray Chamber dan mikrosop optik
\end{abstract}

Kata kunci: pelapisan baja; metode electroplating; sifat fisik dan sifat kimia. 
Pelapisan Baja Karbon Jis S50c Menggunakan Metode Elektroplating: Variasi

Pelapisan Nickel (NI) dan Chrom (CR) Terhadap Sifat Fisik dan Sifat Kimia

\section{Pendahuluan}

Semakin berkembangnya dunia industri sekarang ini, maka semakin banyak teknologi baru yang dikembangkan, tidak terkecuali perkembangan industri pelapisan logam dengan metode elektroplating. Dimana dalam perkembangannya pelapisan dengan metode elektroplating sudah banyak digunakan di dunia industry (Yanto, 2018). Pelapisan baja karbon merupakan salah satu rekayasa dalam menciptakan dan memvariasikan serta merubah sifat fisik dan mekanik pada permukaan logam seperti pada baja karbon yang digunakakan pada sparepart kerndaraan bermotor. Baja Karbon termasuk unsur utama untuk menguatkan baja, sehingga baja harus mengandung karbon sampai kadar tertentu, baja karbon dapat dikelompokkan menjadi 3 bagian yaitu baja karbon rendah, baja karbon sedang dan baja karbon tinggi namun yang akan. Baja jenis digunakan pada komponen industri terutama untuk peralatan perkakas eaksesori kendaraan, dan berbagai alat-alat industri.

Macam-macam pelapisan logam dilakukan dengan metoda antara lain secara celup panas hot dip galvanis, semprot logam metal spraying dan secara listrik elektroplating. Pelapisan secara celup panas hot dip galvanis adalah suatu proses pelapisan dimana logam pelapis dipanaskan hingga mencair, kemudian logam yang dilapislogam dasar dicelupkan ke dalam logam cair tersebut. Pelapisan logam dengan cara semprot metal spraying adalah proses pelapisan logam dengan cara penyemprotan partikel-partikel halus dari logam cair disertai gas bertekanan tinggi serta panas pada logam yang akan dilapislogam dasar. Pelapisan listrik elektroplating adalah suatu proses pengendapan zat atau ion-ion logam pada elektroda negatif katoda dengan cara elektrolisis. Terjadinya suatu endapan pada proses ini adalah karena adanya ion-ion bermuatan listrik berpindah dan suatu elektroda melalui elektrolit yang mana hasil dan elektrolisis tersebut akan mengendap pada katoda, sedangkan endapan yang terjadi bersifat adesif terhadap logam dasar. Selama proses pengendapan atau deposit berlangsung terjadi reaksi kimia pada elektroda dan elektrolit baik reaksi reduksi maupun oksidasi dan diharapkan berlangsung terus menerus menuju arah tertentu secara tetap, untuk itu diperlukan arus listrik searah direct current dan tegangan yang konstant.

(Susanto, 2016) melakukan penilitian tentang pengaruh kuat arus pelapisan baja st42 menggunakan nikel dan crome dari hasil penelitianya bahwa arus optimal pada 5 ampere engan nilai kepadatan tertinggi 2,62 gr/cm3 dan waktu yang optimal untuk pelapisan electroplating nikel yaitu waktu 17 menit dengan nilai kepadatan 2,62 gr/cm3.

Menganalisa kepadatan pada proses pelapisan nikel krom dengan variasi kuat arus dan lama pencelupan baja st 42 . Arus listrik untuk electroplating nikel yang optimal yaitu kuat arus 5 Ampere dengan nilai kepadatan tertinggi 2,62 gr/cm3 dan waktu yang optimal untuk pelapisan electroplating nikel yaitu waktu 17 menit dengan nilai kepadatan 2,62 gr/cm3.

Menurut (Jauhari, 2017) yang meneliti tentang pengaruh variasi tegangan dan arus pada proses pelapisan nikel terhadap kekuatan bending baja st-41. Menyimpulkan bahwa pengaruh pemakaian arus yang terlalu besar menyebabkan partikel-partikel ion nikel yang 
akan menempel pada spesimen terjadi lebih banyak, ini akan mengakibatkan deposit yang terbentuk tidak sempurna, Sedangkan pemakaian tegangan yang semakin tinggi maka pelepasan ion pada anoda semakin cepat, serta pengendapan ion nikel pada spesimen pun lebih cepat, ini terjadi karena kenaikan tegangan mempercepat proses pelepasan ion nikel pada anoda dan pengendapan ion nikel pada katoda.

Menurut (Pratama \& Sakti, 2018) menganalisa perhitungan laju korosi lapisan nikel-krom dengan variasi 2 dan 3 volt, 3, 4, dan 5 Ampere pada knalpot sepeda motor berbahan baja karbon AISI 1010 didapatkan hasil laju korosi paling lambat pada variasi tegangan 3 volt dengan kuat arus 5 Ampere didapat hasil 118,904 mmpy pada media air hujan. Sedangkan laju korosi paling cepat terjadi pada variasi tegangan 2 volt dengan kuat arus 3 Ampere didapat hasil 424,047 mmpy pada media air laut.

Berdasarkan uraian diatas maka penulis mencoba untuk menganalisis pengaruh variasi pelapis dengan waktu dan kuat arus proses electroplating terhadap kekerasan, ketebalan, laju korosi dan morfologi baja menggunakan pelapisan nikel dan pelapisan krom.

Berdasarkan permasalahan yang sudah dijelaskan, adapun tujuan dari penelitian ini adalah (1) Mengetahui proses electroplating (2) Mengetahui pengaruh kuat arus dan lama pencelupan (3) Mengetahui morfologi hasil electroplating.

\section{Metode Penelitian}

Proses penelitian pelapisan baja karbon JISS50C dengan metode electroplating nikel dan krom dilakukan di Laboratorium Teknik Mesin Universitas Sigaperbangsa Karawang, sedangkan pengujian serta analisa hasil eksperimen material di Balai Besar Bahan dan Barang Teknik (B4T) Bandung dan, Pusat Penelitian Fisika di LIPI Serang. Pengujian material diantaranya :

1. Alat

a. Bak Penampung Elektrolit

Digunakan untuk menampung cairan elektrolit selama proses electroplating. Bak penampung ini menampung cairan hingga 50 liter.

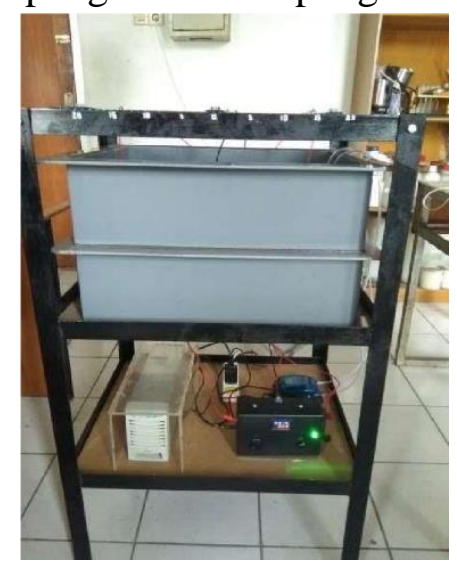

\section{Gambar 1 Alat dan Komponen Proses Elektroplating}

b. Power Supply 
Pelapisan Baja Karbon Jis S50c Menggunakan Metode Elektroplating: Variasi Pelapisan Nickel (NI) dan Chrom (CR) Terhadap Sifat Fisik dan Sifat Kimia

Sebagai sumber arus searah (DC) pada proses electroplating. Ada 2 macam power supply yang digunakan yaitu dengan kuat arus $10 \mathrm{~A}$ dan 15 A dan masing masing memiliki tegangan yang sama yaitu $12 \mathrm{~V}$.

c. Penjepit Anoda dan Katoda

Digunakan untuk menjepit Anoda yang dihubungkan pada terminal positif, dan katoda yang dihubungkan pada terminal negatif. Anoda merupakan material pelapis pada proses electroplating, sedangkan katoda merupakan material yang akan dilapisi.

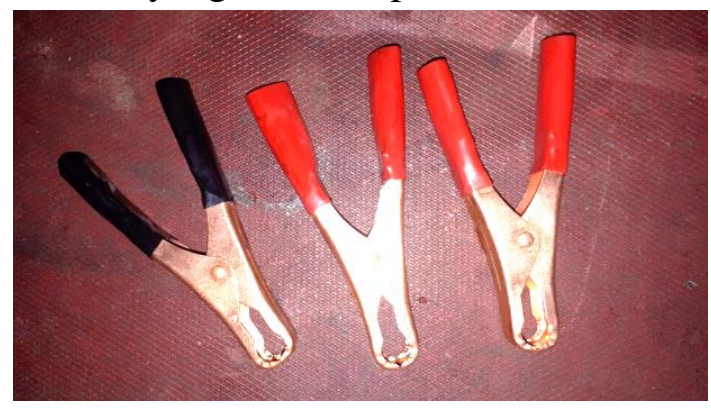

d. Heater

Gambar 2 Penjepit Anoda dan Katoda

Digunakan sebagai pemanas cairan elektrolit agar sampai pada suhu $40^{\circ} \mathrm{C}$ $-60^{\circ} \mathrm{C}$.

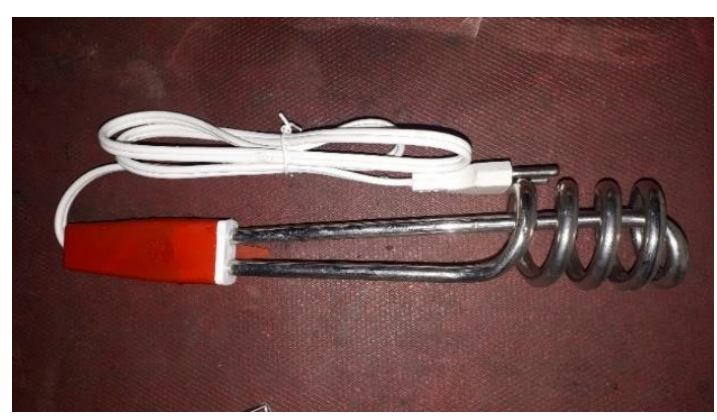

Gambar 3 Heater

e. Aerator

Digunakan untuk system agitasi pada cairan elektrolit saat proses electroplating.

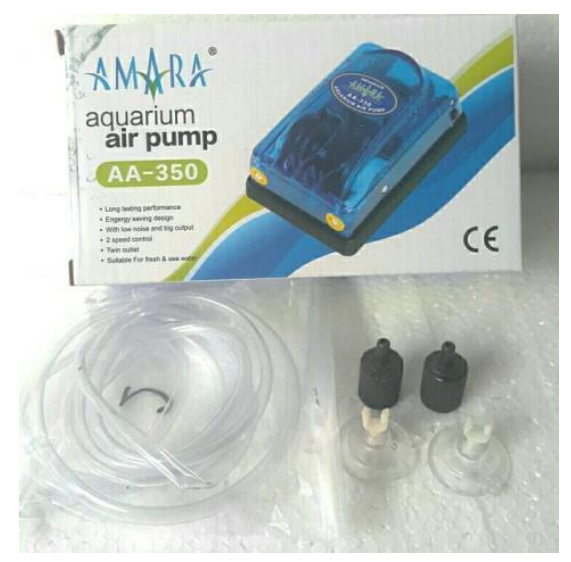


f. Gerinda Listrik

\section{Gambar 4 Aerator}

Gerinda listrik digunakan untuk menghaluskan permukaan benda kerja sehingga memenuhi standard dan untuk menghilangkan lapisan oksidasi/karat pada material.

g. Alat Uji Kekerasan Vickers

Merupakan sebuah alat pengukur kekerasan yang digunakan dengan cara menekan benda uji atau spesimen dengan indentor intan yang berbentuk piramida dengan alas segi empat dan besar sudut dari permukaanpermukaan yang berhadapan 136 setelah spesimen dilapisi.

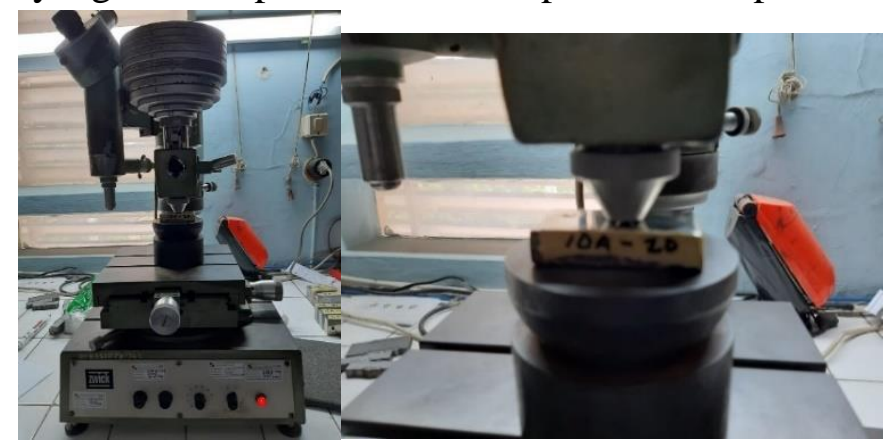

Gambar 5 Mesin Hardness Vickers

h. Salt Spray Chamber

Salt Spray Chamber merupakan sebuah alat pengukur laju korosi. Pada dasarnya Uji Korosi dapat dilakukan baik secara simulatif didalam laboratorium ataupun secara langsung di lapangan. Pengujian Laju Korosi ini menggunakan alat uji kabut garam (salt spray chamber), dengan waktu ekspos spesimen uji 24 jam secara periodik. Pengujian kabut garam memakai standar SNI 07-0414-89 dengan tekanan 19-22 psi. Dalam pengujian ini ada 12 spesimen yang diuji termasuk dengan satu spesimen raw material.

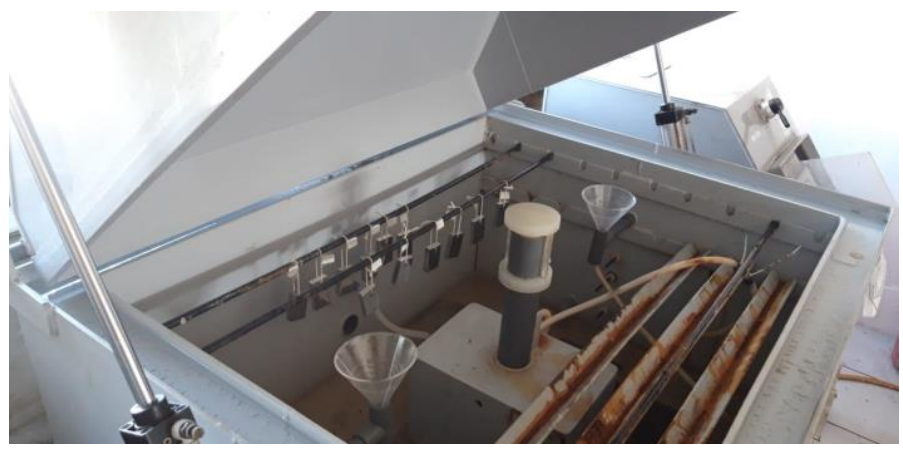

Gambar 6 Mesin Salt Spray Chamber

i. Mikroskop Optik

Berfungsi untuk mengamati struktur mikro pada material yang sudah dilapisi dengan perbesaran 500x. 


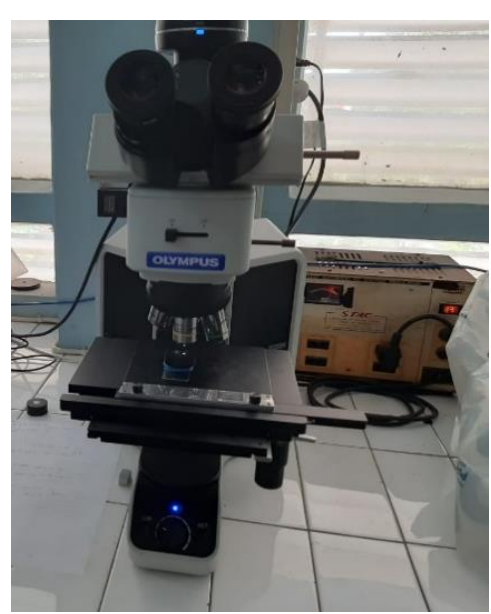

2. Bahan

\section{Gambar 7 Mesin Mikroskop Optik}

a. Anoda

Anoda yang digunakan adalah anoda Nikel dan Krom terlarut, berperan sebagai media pendistribusian endapan elektrolit, adanya arus listrik yang mengalir melalui elektrolit diantara kedua elektroda, maka pada anoda akan terjadi pelepasan ion logam dan oksigen atau disebut Reduksi.

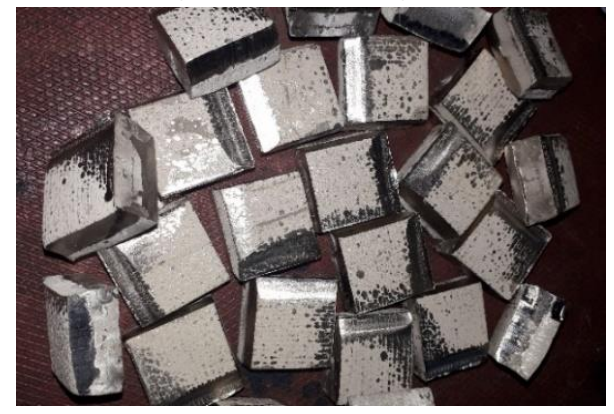

Gambar 8 Anoda Nikel

b. Katoda

Katoda adalah matrial yang akan dilapisi, dan material yang digunakan yaitu baja karbon rendah S50C dengan dimensi 50 x30 x5 (mm)

c. Baja Karbon JISS50C

Spesimen yang digunakan pada penelitian ini adalah Baja Karbon JISS50C, yaitu baja karbon sedang. Baja yang digunakan pada penelitian ini sebanyak 48 sample / spesimen.

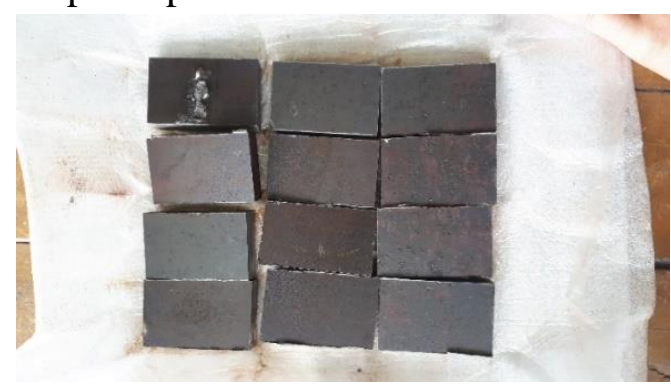

Gambar 9 Baja S50C 
d. Larutan Elektrolit

Larutan yang digunakan pada penelitian ini yaitu larutan all sulfuric, larutan all chloride, larutan sulfuric acid chloride larutan chromic acid. Komposisi setiap larutan mengacu pada rekomendasi dari peneliti peneliti sebelumnya

a) Larutan Elektrolit All Sulfuric - Nikel Sulfat (NiSO4) $=300$ gram/liter - Asam Borat $(\mathrm{H} 3 \mathrm{BO} 3)=40$ gram/liter

b) Larutan Elektrolit All Chloride - Nikel Klorida $(\mathrm{NiCl})=240$ gram/liter - Asam Borat $(\mathrm{H} 3 \mathrm{BO} 3)=30$ gram/liter

c) Larutan Elektrolit Sulfuric Acid Chloride - Nikel Sulfat (NiSO4) = 195 gram/liter - Nikel Klorida $(\mathrm{NiCl})=175$ gram/liter - Asam Borat $(\mathrm{H} 3 \mathrm{BO} 3)=40$ gram/liter

d) Larutan Elektrolit Cromic Acid (CrO3)

Asam kromat merupakan satu-satunya sumber ion krom yang akan melapisi benda kerja. Karena anoda yang digunakan tidak larut, maka konsentrasi ion krom lama kelamaan akan berkurang. Hal ini perlu diantisipasi dengan penambahan asam kromat untuk menjaga kadar krom dalam larutan. Takaran asam kromat yang digunakan untuk membuat larutan elektrolit sebesar $150 \mathrm{gr} / 1$.

e) Asam Sulfat

Asam sulfat adalah salah satu katalis yang berperan untuk mempercepat terjadinya reaksi pengendapan ion logam. Takaran asam sulfat yang digunakan untuk membuat larutan elektrolit sebesar $0,87 \mathrm{gr} / 1$

f) Aquades

Aquades adalah cairan pelarut untuk pembuatan larutan elektrolit. Air destilasi digunakan sebagai pelarut karena tidak mengandung mineral yang dapat mengganggu proses elektroplating.

g) Katalis

Katalis memiliki peran sebagai pengendap ion chrome. Takaran katalis yang digunakan untuk pembuatan larutan elektrolit sebesar $15 \mathrm{ml} / \mathrm{l}$.

3. Standarisasi Spesimen

Standarisasi spesimen disesuaikan dengan jenis pengujian yang akan dilakukan. Pengujian Mikroskopik, Pengujian Kekerasan Vickers, Pengujian laju korosi, dan Pengujian SEM dengan standarisasi spesimen yang berdiamensi ukuran 30 × 50 × $12 \mathrm{~mm}$ dan 30 × 50 × $10 \mathrm{~mm}$ dan ditambahkan lubang $\varnothing 5 \mathrm{~mm}$ berfungsi untuk lubang pengait saat pengujian.

4. Langkah-Langkah Penelitian

Langkah-langkah penelitian dibagi menjadi 3 tahap, yaitu tahap preparasi sampel baja, tahap pembuatan larutan elektrolit didalam proses elektroplating serta tahap pengujian baja. 


\section{Hasil dan Pembahasan}

1. Hasil Proses Elektroplating

Setelah proses elektroplating maka didapatlah hasil pelapisan nikel dan krom pada baja S50C dengan beberapa variasi ditunjukan pada Gambar 10 Spesimen Hasil Elektroplating.

(a)

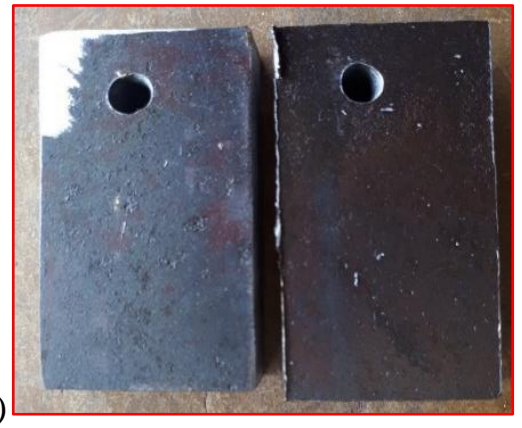

(b)

\section{Gambar 10 Spesimen Hasil Elektroplating}

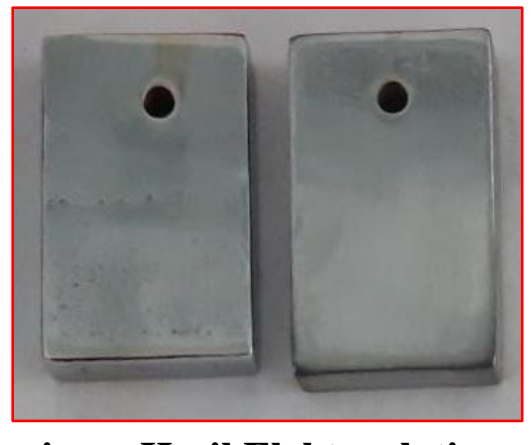

Pada gambar 10 (a) menunjukan spesimen yang belum mengalami proses elektroplating, sedangkan Gambar 10 (b) merupakan hasil pelapisan dengan jenis larutan Nickel Sulfat $\left(\mathrm{NiSO}_{4}\right)$ dan Chromic Acid $\left(\mathrm{CrO}_{3}\right)$. Hasil spesimen diatas memiliki perbedaan yang signifikan dari segi penampilan. Pelapisan dengan jenis larutan yang berbeda memiliki perbedaan yang signifikan dari segi penampilan, karena nikel dan krom tetap mampu menutupi seluruh permukaan baja. Hal ini disebabkan karena ion yang bergerak secara merata dari anoda ke katoda akibat dari adanya arus listrik dan tegangan yang mengalir pada larutan elektrolit, proses pre treatment, proses post treament, dan juga sifat nikel dan krom yang mampu melapisi permukaan baja menjadi tampak lebih indah.

Selanjutnya, peneliti akan membandingkan hasil spesimen proses elektroplating dari pelapisan nikel dan pelapisan krom dengan variasi kuat arus 10A dan 15A.

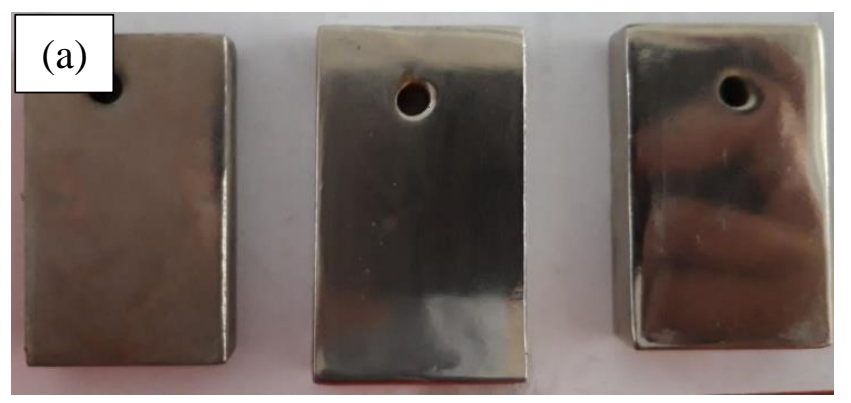



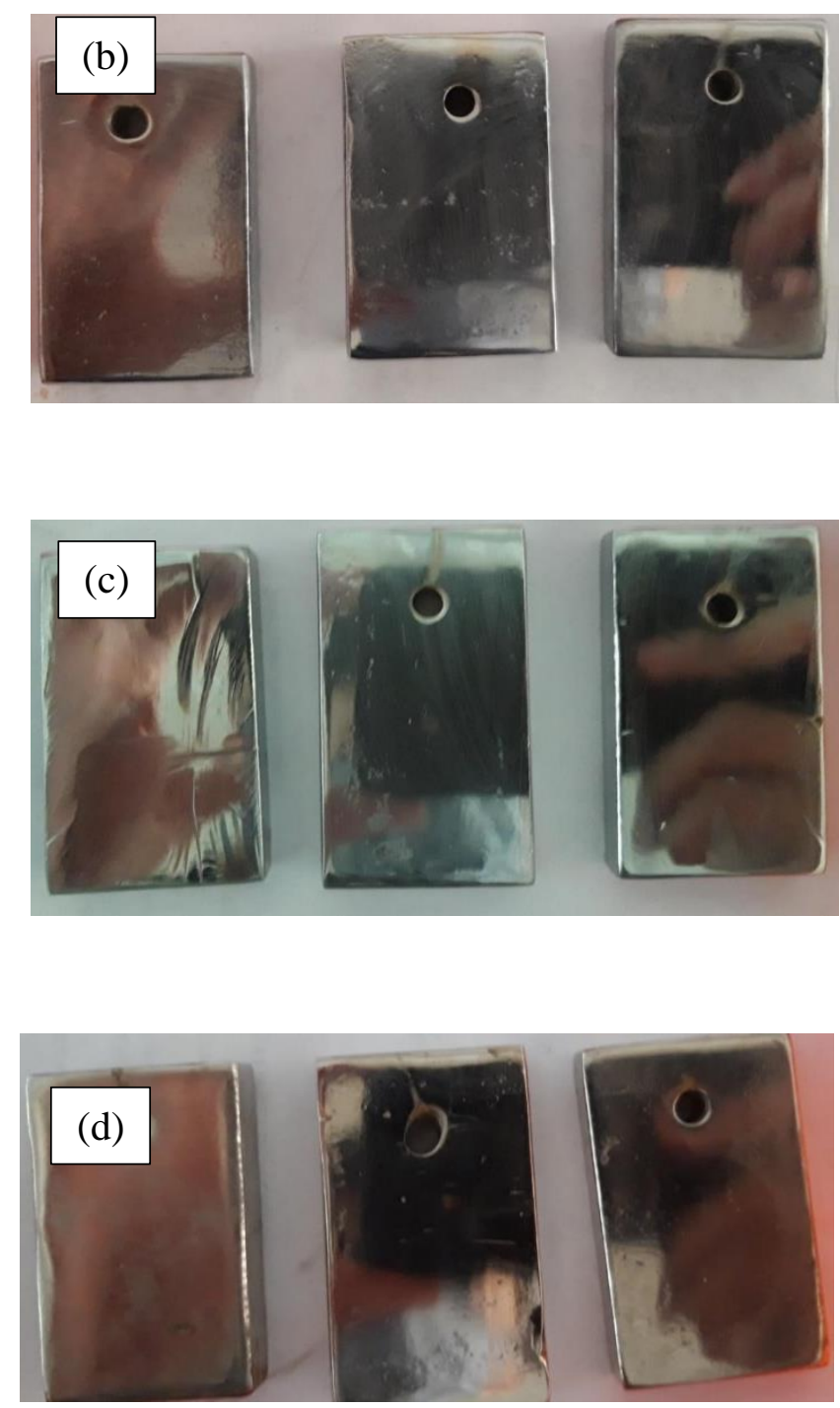

\section{Gambar 11 Hasil spesimen Proses Elektroplating Pelapisan Nikel dan Pelapisan Krom dengan variasi kuat arus 10A dan 15A}

Pada gambar 11 diatas adalah spesimen pelapisan nikel dan krom dengan variasi kuat arus 10A dan 15A dengan waktu 10, 15 dan 20 menit. Gambar 11 (a) menunjukan spesimen pelapisan nikel dengan variasi kuat arus 10A dengan waktu 10, 15 dan 20 menit, Gambar 11 (b) spesimen pelapisan nikel dengan variasi kuat arus 15A, Gambar 4.2 (c) spesimen pelapisan krom dengan variasi kuat arus 10A dan Gambar 11 (d) menunjukan spesimen pelapisan krom dengan variasi kuat arus 15A. Hasil spesimen diatas memiliki perbedaan yang signifikan dari segi penampilan. Pelapisan dengan kuat arus yang berbeda juga sangat mempengaruhi ketebalan pada lapisan baja tersebut. Pada spesimen diatas terlihat unsur nikel telah menutupi seluruh permukaan baja sehingga baja mengalami perubahan menjadi berwarna kuning dan permukaan yang lebih halus sehingga tampak luarnya lebih indah dari sebelumnya. Dan terlihat unsur krom telah menutupi seluruh 
permukaan baja sehingga baja mengalami perubahan menjadi berwarna silver cerah dan permukaan yang lebih mengkilap dari sebelumnya.

Penelitian sebelumnya oleh (Putra, 2012) pelapisan menggunakan pelapis nikel cobalt mampu menambah keindahan tampak luar suatu benda atau produk dikarenakan perpindahan larutan nikel dari anoda ke katoda. Kemudian penelitian yang dilakukan oleh (B. Widodo \& Asmoro, 2012) menjelaskan bahwa pelapisan nikel menggunakan larutan jenis all sulfat dan all Klorid mampu memperindah tampilan (decorative) dari material. Selanjutnya penelitian dari (Bimariga, 2018) menggunakan larutan Nickel Sulfat dan Hard Chromium menyimpulkan bahwa perlunya electroplating nikel-hard chromium dapat meningkatkan ketahanan korosi yang tinggi .

Oleh karena itu pelapisan baja karbon JIS S50C dengan nikel dan krom menggunakan metode electroplating sangat berguna untuk memperindah tampilan dari material, selain memperindah juga meningkatkan ketahanan korosi pada material tersebut. Maka, pada subbab berikut akan dibahas tentang hasil pengujian korosi pada material (Hamzah \& Iqbal, 2008).

1. Hasil dari engujian Laju Korosi

Setelah Proses Pelapisan selesai, hasilnya kemudian dilanjutkan dengan tahapan pengujian. Diantaranya adalah Pengujian Laju Korosi.

Gambar 12 merupakan spesimen baja karbon JIS S50C yang sudah di coating dengan Nickel dan Chrom sebelum mengalami proses uji kabut garam masih terlihat mengkilap berwarna silver tanpa ada korosi.

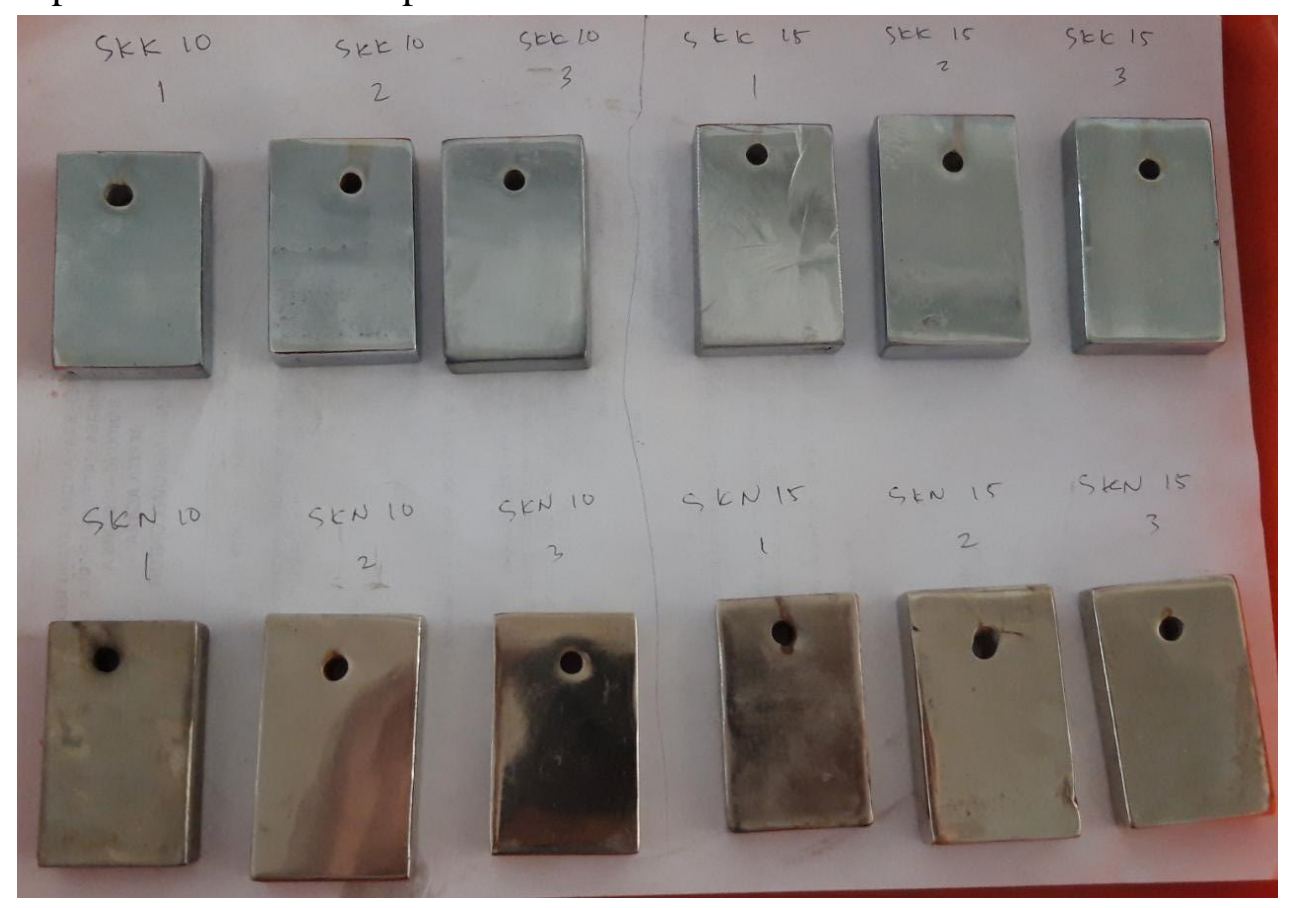

Gambar 12 Spesimen sebelum melalui Pengujian Tahan Korosi dengan Semprot Kabut Garam 


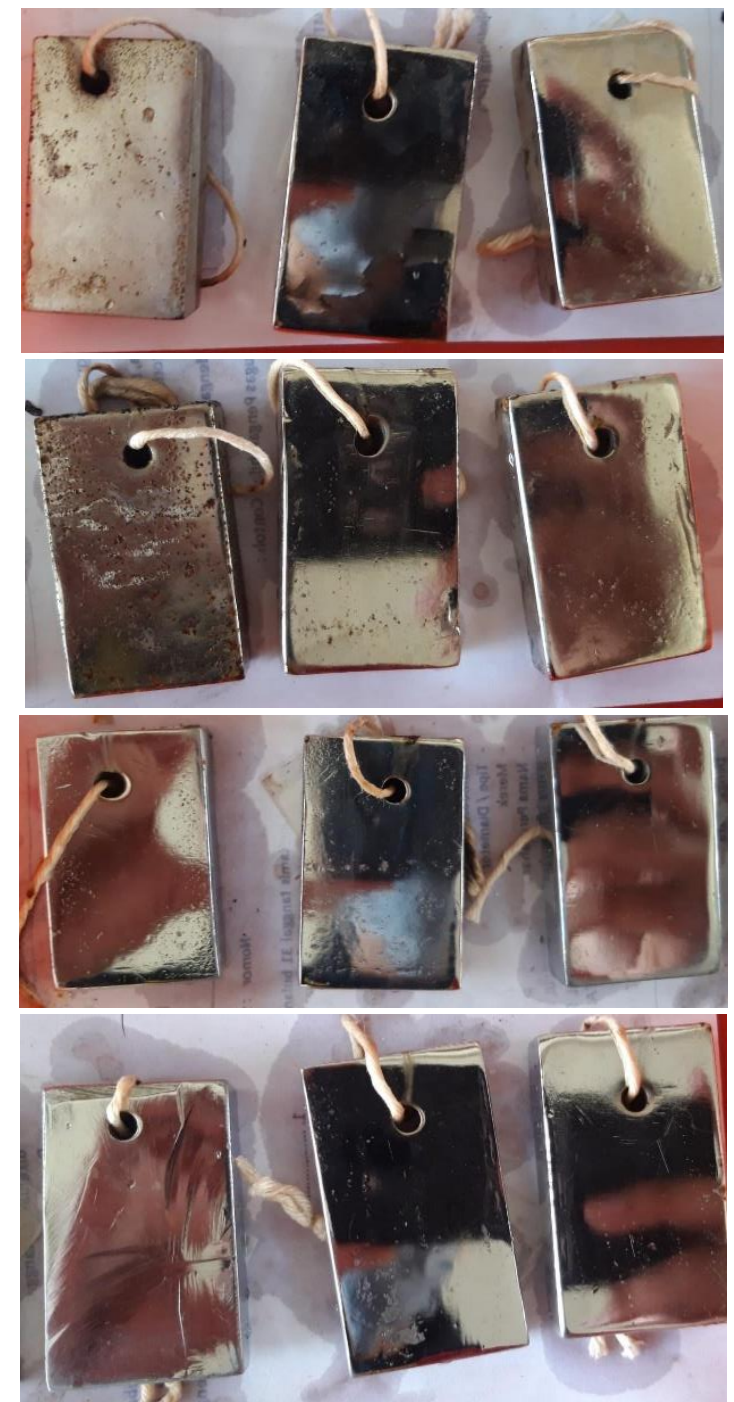

\section{Gambar 13 Spesimen Variasi Pelapisan Nikel dan Krom Arus 10A dengan waktu 10, 15 dan 20 menit}

Dari hasil pengujian tahan korosi terlihat bahwa semua spesimen mengalami perubahan fisik dan perubahan yang telihat jelas pada rusaknya permukaan spesimen. Gambar 13 (a) dan Gambar 13 (b) merupakan spesimen pelapisan nikel yang telah diuji laju korosi dan termasuk pada spesimen yang paling rusak permukaan nya, ini terjadi akibat dari sifat baja karbon yang lebih mudah teroksidasi karena tipisnya pelapis proteksinya, kemudian Gambar 13 (c) dan Gambar 13 (d) merupakan spesimen yang sudah dilapisi oleh nikel krom dengan tiga waktu berbeda hanya sedikit permukaan yang rusak, secara tampak terlihat perbedaan yang signifikan dari spesimen kedua jenis larutan tersebut.

Pengujian ketahanan korosi dilakukan selama 24 jam dengan metode Uji Tahan Korosi dengan Semprot Kabut Garam berstandar SNI 07-0414-89 menggunakan media korosif $\mathrm{NaCl}$ (Natrium Klorida) 1\% hanya didapatkan selesih berat sebelum pengujian 
Pelapisan Baja Karbon Jis S50c Menggunakan Metode Elektroplating: Variasi Pelapisan Nickel (NI) dan Chrom (CR) Terhadap Sifat Fisik dan Sifat Kimia

dan setelah pengujian yang dilambangkan dengan (W), kemudian digunakan kedalam persamaan untuk menghitung Laju Korosi (CR).

Pada tabel dibawah menunjukan nilai uji laju korosi dari hasil pelapisan nikel dan pelapisan krom.

Tabel 1 Hasil pengujian laju korosi

\begin{tabular}{lllll}
\hline No & $\begin{array}{l}\text { Kode } \\
\text { Spesimen }\end{array}$ & W (gram) & A $\left(\right.$ in $\left.^{2}\right)$ & $\begin{array}{l}\text { Laju Korosi } \\
(m p y)\end{array}$ \\
\hline 1 & SKN10.1 & 0.000078 & 181,24 & 230,79771 \\
\hline 2 & SKN10.2 & 0.000051 & 181,24 & 150,90619 \\
3 & SKN10.3 & 0.000037 & 181,24 & 109,48096 \\
\hline 4 & SKN15.1 & 0.000068 & 181,24 & 201,20826 \\
\hline 5 & SKN15.2 & 0.000043 & 181,24 & 127,23463 \\
\hline 6 & SKN15.3 & 0.000025 & 181,24 & 73,97362 \\
\hline 7 & SKK10.1 & 0,000020 & 181,24 & 59,17890 \\
8 & SKK10.2 & 0,000014 & 181,24 & 41,42523 \\
9 & SKK10.3 & 0,000010 & 181,24 & 29,58945 \\
10 & SKK15.1 & 0,000016 & 181,24 & 47,34312 \\
11 & SKK15.2 & 0,000007 & 181,24 & 20,71261 \\
12 & SKK15.3 & 0,000005 & 181,24 & 14,79472 \\
\hline
\end{tabular}

Tabel 1 menunjukan hasil pengujian dan perhitugan laju korosi setiap spesimen dalam satuan meters per years (mpy) dan dapat disajikan kedalam grafik berikut ini.

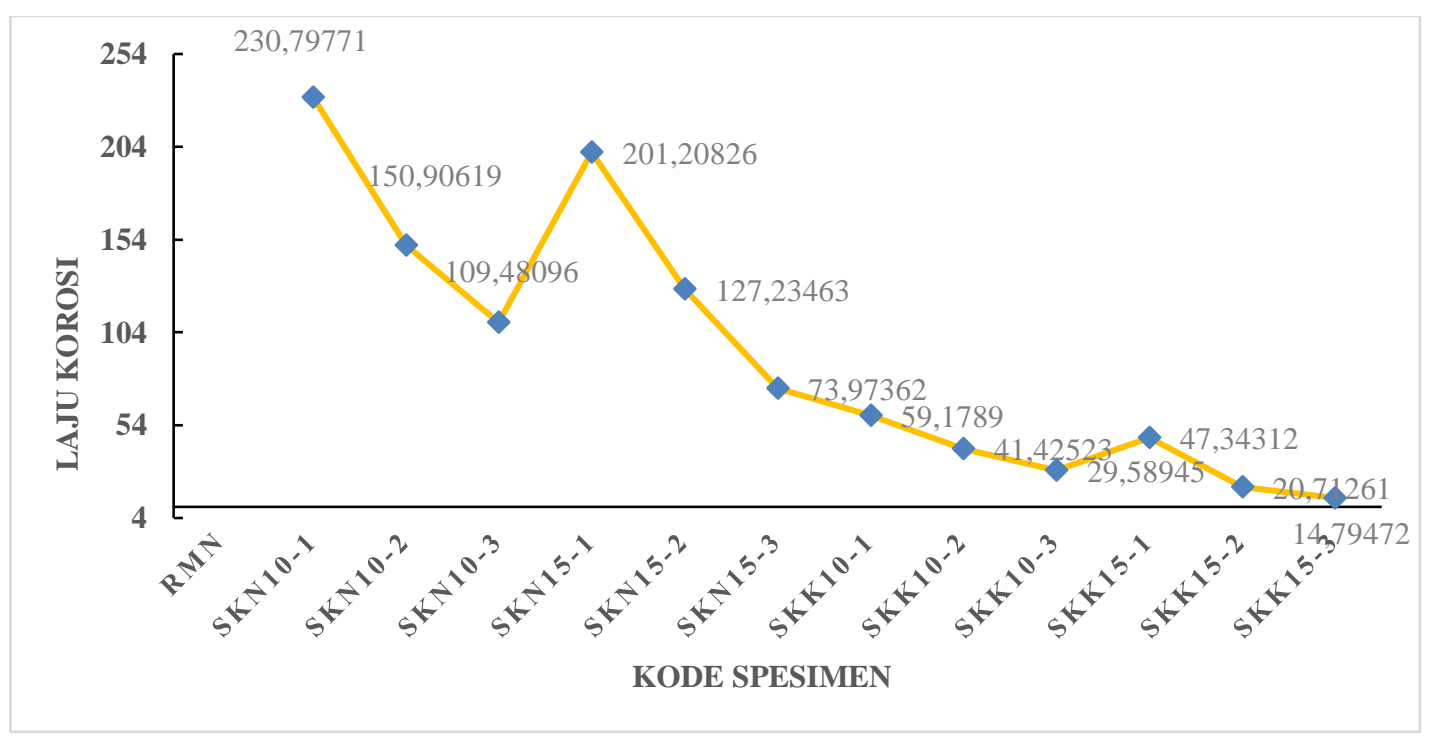

Gambar 14 Grafik nilai hasil pengujian laju korosi

Berdasarkan keterangan grafik yang terlihat pada Gambar 14 menjelaskan bahwa spesimen yang dilapisi oleh nikel mampu melindungi baja karbon dari kerusakan akibat teroksidasi dibanding spsimen yang tidak dilapisi oleh nikel atau disebut raw material 
dengan kode spesimen RL. Laju korosi terendah merupakan kode spesimen SKK15-3 dengan nilai laju korosi 14,79472 mpy dan nilai laju korosi tertinggi yaitu 230,79771 mpy dengan kode spesimen SKN10-1. Dalam hal ini jenis larutan juga mempengaruhi laju korosi setiap spesimen dikarenakan semakin besarnya kandungan logam pada setiap jenis larutan akan mempengaruhi kestabilan dan kenaikan kuat arus listrik dalam proses electroplating maka akan menyebabkan ion pada logam pelapis yang terlepas (anoda) semakin banyak mengendap di permukaan yang akan dilapisi (katoda). Sehingga semakin banyaknya ion-ion yang mengendap di permukaan logam akan mempengaruhi ketebalan dan kerapatan suatu lapisan. Ketika suatu lapisan memiliki ketebalan yang tinggi dan tingkat kerapatan yang tinggi maka lapisan tersebut akan semakin sulit untuk teroksidasi.

Penelitian sebelumnya yang dilakukan (Sandi et al., 2017) penelitian tsb menghasilkan semakin lama waktu elektroplating yang digunakan maka, semakin meningkat massa baja serta kadar Zn dan Mn yang akan mengakibatkan laju korosi yang semakin menurun. Hasil laju korosi terendah didapatkan pada waktu 50 detik dengan arus

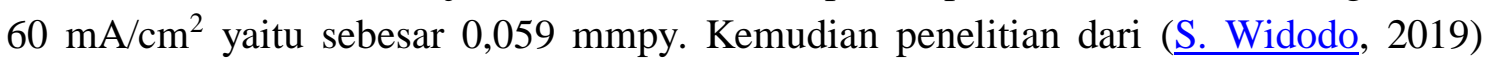
menggunakan jenis larutan all sulfat dan di uji dengan lingkungan $0.9 \% \mathrm{NaCl}$ (Natrium Klorida) selama 24 jam mendapatkan niali laju korosi sebesar 0.007 mmpy.

Oleh karena itu pemilihan jenis larutan sangat berpengaruh terhadap laju korosi material, pada pengujian ini media yang digunakan adalah larutan garam $\mathrm{NaCl}$ yang disemprotkan pada permukaan spesimen, karena semakin tebal dan rapatnya suatu lapisan nikel mengakibatkan semakin sulitnya larutan $\mathrm{NaCl}$ untuk bisa mengoksidasi spesimen tersebut dan ditambah lagi dengan sifat nikel yang tahan karat, sehingga permukaan baja karbon sulit untuk teroksidasi. Semakin besarnya logam yang terkandung dalam suatu larutan elektrolit berbanding lurus dengan semakin kecilnya laju korosi material tersebut. Dari hasil pengujian laju korosi diatas, juga dapat mempengaruhi kekerasan dari material yang sudah dilapis dengan nikel dan krom tersebut, maka pada subbab berikut peneliti akan menjelaskan hasil dari pengujian kekerasan pada material.

\section{Hasil dari Pengujian Kekerasan dengan Vickers Hardness}

Pengujian kekerasan dalam penelitian adalah pengujian merusak dengan metode Vickers. Dalam pengujian ini menggunakan pembebanan sebesar $10 \mathrm{kgf} / \mathrm{mm}^{2}$ dan setiap spesimen dikenai 3 titik injakan.

Pengujian Vickers ini dikenal juga sebagai Diamond Pyramid Hardness test (DPH). Uji kekerasan vickers menggunakan indentor piramida intan, besar sudut antar permukaan piramida intan yang saling berhadapan adalah 136 derajat. Terbagi menjadi dua rentang kekuatan yang berbeda, yaitu micro $(10 \mathrm{~g}-1000 \mathrm{~g})$ dan macro (1 kg $100 \mathrm{~kg})$.

Metode Vickers sebagai pengujian keras ini dilaksanakan dengan cara menekan material atau spesimen uji dengan indentor intan dengan bentuk piramida dengan alas segi empat dan besar sudut dari permukaan yang berhadapan 136 derajat. Pada penekanan dengan indentor ini akan menghasilkan jejak atau lekukan pada permukaan material uji. 
Pelapisan Baja Karbon Jis S50c Menggunakan Metode Elektroplating: Variasi Pelapisan Nickel (NI) dan Chrom (CR) Terhadap Sifat Fisik dan Sifat Kimia

Tabel 2 Hasil Uji Hardness Vickers Pelapisan Nikel dengan arus 10 Ampere

\begin{tabular}{|c|c|c|c|c|c|c|}
\hline No & Koc & simen & Nilai Ke & rasan & & Hasil Pengujian \\
\hline & $-\mathrm{R}$ & & 1 & 2 & 3 & \\
\hline & & & 91,0 & 91,0 & 91,0 & \\
\hline 1 & & & 91 & & & \\
\hline & 2 & SNK10-1 & 217 & 218 & 215 & 217 \\
\hline & 3 & SNK10-2 & 151 & 147 & 148 & 148 \\
\hline & 4 & SNK10-3 & 212 & 206 & 202 & 206 \\
\hline
\end{tabular}

Keterangan: RM = Raw Material

SNK10-1 = Sample Nikel Kekerasan arus 10 Ampere - titik ke 1

SNK10-2 = Sample Nikel Kekerasan arus 10 Ampere - titik ke 2

SNK10-3 = Sample Nikel Kekerasan arus 10 Ampere - titik ke 3

Hasil pengujian kekerasan pada Tabel 2 menghasilkan nilai kekerasan pada sample nikel kekerasan dengan arus 10 Ampere ke-1 mendapatkan nilai kekerasan sebesar 217 HV, kemudian nilai kekerasan pada sample nikel kekerasan dengan arus 10 Ampere ke-2 mendapatkan nilai kekerasan sebesar $148 \mathrm{HV}$ dan selanjutnya pada nilai kekerasan sample nikel kekerasan dengan arus 10 Ampere mendapatkan nilai kekerasan sebesar 206 HV. Dari hasil tsb dapat digambarkan dalam sebuah grafik seperti pada Gambar 15 dibawah ini.

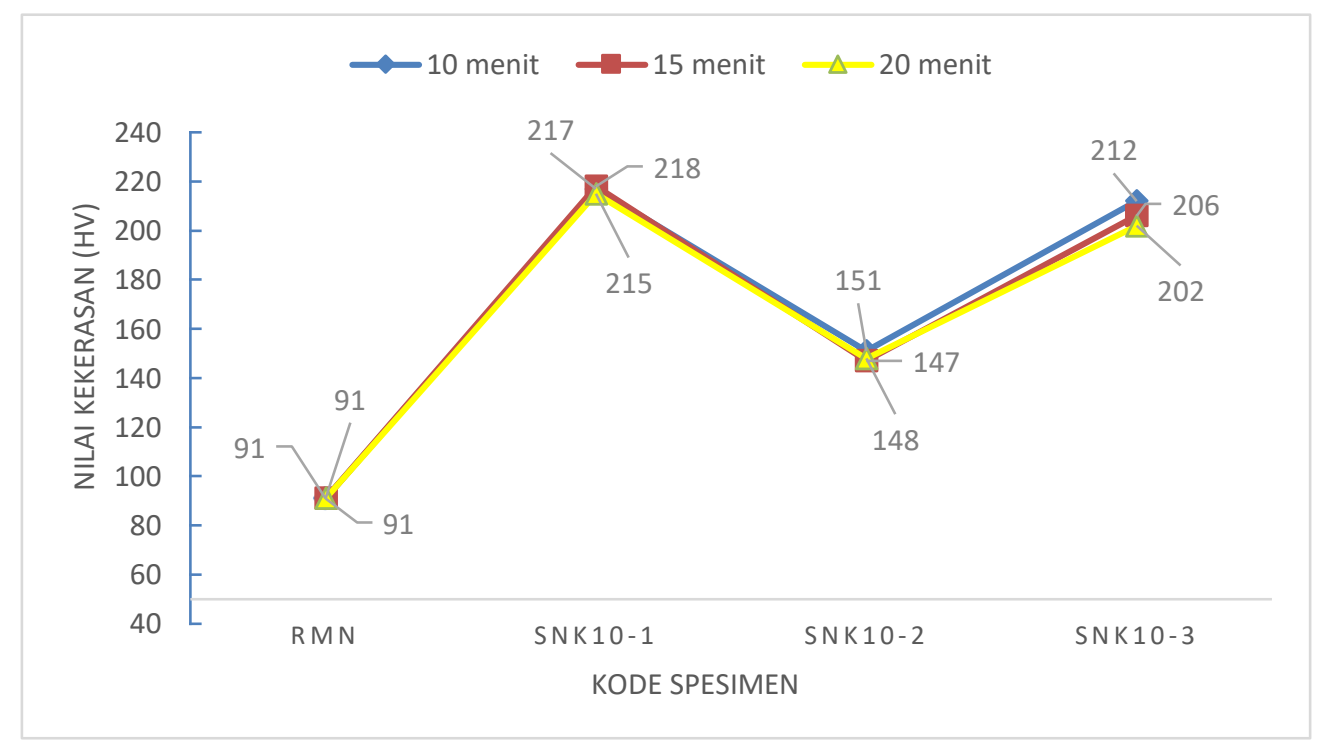




\section{Gambar 15 Grafik hasil pengujian kekerasan pelapisan nikel dengan kuat arus \\ 10A}

Pada gambar 15 menunjukan hasil pengujian kekerasan, dimana terlihat perbedaan kekerasan antara material awal yang belum mengalami proses coating dan material yang sudah dicoating dengan variasi waktu 10, 15, 20 menit. Untuk sampel raw material mempunyai nilai kekerasan $91 \mathrm{HV}$. Untuk sampel yang telah di electroplating dengan kuat arus 10 Ampere mempunyai nilai kekerasan 217 HV pada waktu 10 menit, 148 HV pada waktu 15 menit dan 206 HV pada waktu 20 menit. Dapat kita lihat dari Grafik bahwa mengalami peningkatan dari nilai kekerasan raw material.

Tabel 3 Hasil Uji Hardness Vickers dengan kuat arus 15 Ampere

\begin{tabular}{|c|c|c|c|c|c|c|}
\hline \multirow[t]{3}{*}{ No } & \multicolumn{2}{|c|}{ Kode Spesimen } & \multicolumn{2}{|c|}{ Nilai Kekerasan } & \multicolumn{2}{|r|}{ Hasil Pengujian } \\
\hline & & & 1 & 2 & 3 & \multirow{2}{*}{ (HV) } \\
\hline & & & 91,0 & 91,0 & 91,0 & \\
\hline 1 & & RM & 91 & & & \\
\hline & 2 & SNK15-1 & 206 & 203 & 206 & 205 \\
\hline & 3 & SNK15-2 & 193 & 196 & 195 & 194 \\
\hline & 4 & SNK15-3 & 198 & 196 & 196 & 196 \\
\hline
\end{tabular}

Keterangan : RM = Raw Material

SNK15-1 = Sample Nikel Kekerasan arus 15 Ampere - titik ke 1

SNK15-2 = Sample Nikel Kekerasan arus 15 Ampere - titik ke 2

SNK15-3 = Sample Nikel Kekerasan arus 15 Ampere - titik ke 3

Hasil pengujian kekerasan pada Tabel 3 menghasilkan nilai kekerasan pada sample nikel kekerasan dengan arus 15 Ampere ke-1 mendapatkan nilai kekerasan sebesar $205 \mathrm{HV}$, kemudian nilai kekerasan pada sample nikel kekerasan dengan arus 15 Ampere ke-2 mendapatkan nilai kekerasan sebesar 194 HV dan selanjutnya pada nilai kekerasan sample nikel kekerasan dengan arus 15 Ampere mendapatkan nilai kekerasan sebesar 196 HV. Dari hasil tsb dapat digambarkan dalam sebuah grafik seperti pada Gambar 4.7 dibawah ini.

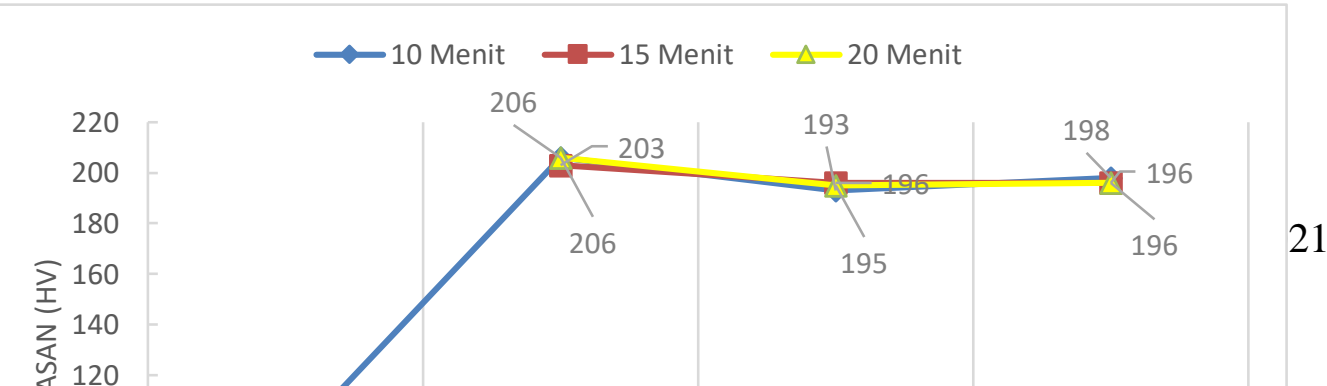


Pelapisan Baja Karbon Jis S50c Menggunakan Metode Elektroplating: Variasi Pelapisan Nickel (NI) dan Chrom (CR) Terhadap Sifat Fisik dan Sifat Kimia

\section{Gambar 16 Grafik hasil pengujian kekerasan pelapisan nikel dengan kuat arus $15 \mathrm{~A}$}

Untuk sampel yang telah di electroplating dengan kuat arus 15 Ampere mempunyai nilai kekerasan $205 \mathrm{HV}$, meningkat dari nilai kekerasan raw material. Untuk sampel yang telah di electroplating dengan kuat arus 10 Ampere mempunyai nilai kekerasan $217 \mathrm{HV}$, meningkat dari nilai kekerasan raw material dan lebih tinggi dari nilai kekerasan kuat arus $10 \mathrm{~A}$ ampere.

Data tersebut menunjukkan bahwa semakin besar kuat arus yang diberikan maka semakin dikit ion dari anoda sebagai bahan pelapis yang tereduksi dan terbawa menempel di permukaan logam induk sebagai katoda. Sehingga spesimen memiliki nilai kekerasan yang semakin baik terutama bila dibandingkan dengan spesimen yang tidak dilapisi.

3. Data Hasil Pengujian Pelapisan Nikel Krom

Tabel 4 Hasil Uji Hardness Vickers dengan arus 10A

\begin{tabular}{|c|c|c|c|c|c|c|}
\hline No & Koc & simen & Nilai K & erasa & & Hasil Pengujian \\
\hline & $-\mathrm{Ra}$ & & 1 & 2 & 3 & \\
\hline & & & 91,0 & 91,0 & 91,0 & \\
\hline 1 & & & 91 & & & \\
\hline & 2 & SKK10-1 & 176 & 179 & 176 & 177 \\
\hline & 3 & SKK10-2 & 160 & 156 & 159 & 158 \\
\hline & 4 & SKK10-3 & 187 & 191 & 193 & 190 \\
\hline
\end{tabular}

Keterangan : RM = Raw Material

SKK10-1 = Sample Nikel Krom Kekerasan kuat arus 10 Ampere - titik ke 1

SKK10-2 = Sample Nikel Krom Kekerasan kuat arus 10 Ampere - titik ke 2

SKK10-3 = Sample Nikel Krom Kekerasan kuat arus 10 Ampere - titik ke 3 
Hasil pengujian kekerasan pada Tabel 4 menghasilkan nilai kekerasan pada sample nikel krom kekerasan dengan arus 10 Ampere ke-1 mendapatkan nilai kekerasan sebesar $177 \mathrm{HV}$, kemudian nilai kekerasan pada sample nikel krom kekerasan dengan arus 10 Ampere ke-2 mendapatkan nilai kekerasan sebesar $158 \mathrm{HV}$ dan selanjutnya pada nilai kekerasan sample nikel krom kekerasan dengan arus 10 Ampere mendapatkan nilai kekerasan sebesar 190 HV. Dari hasil pengujian kekerasan tsb dapat digambarkan dalam sebuah grafik seperti pada Gambar 17 dibawah ini.

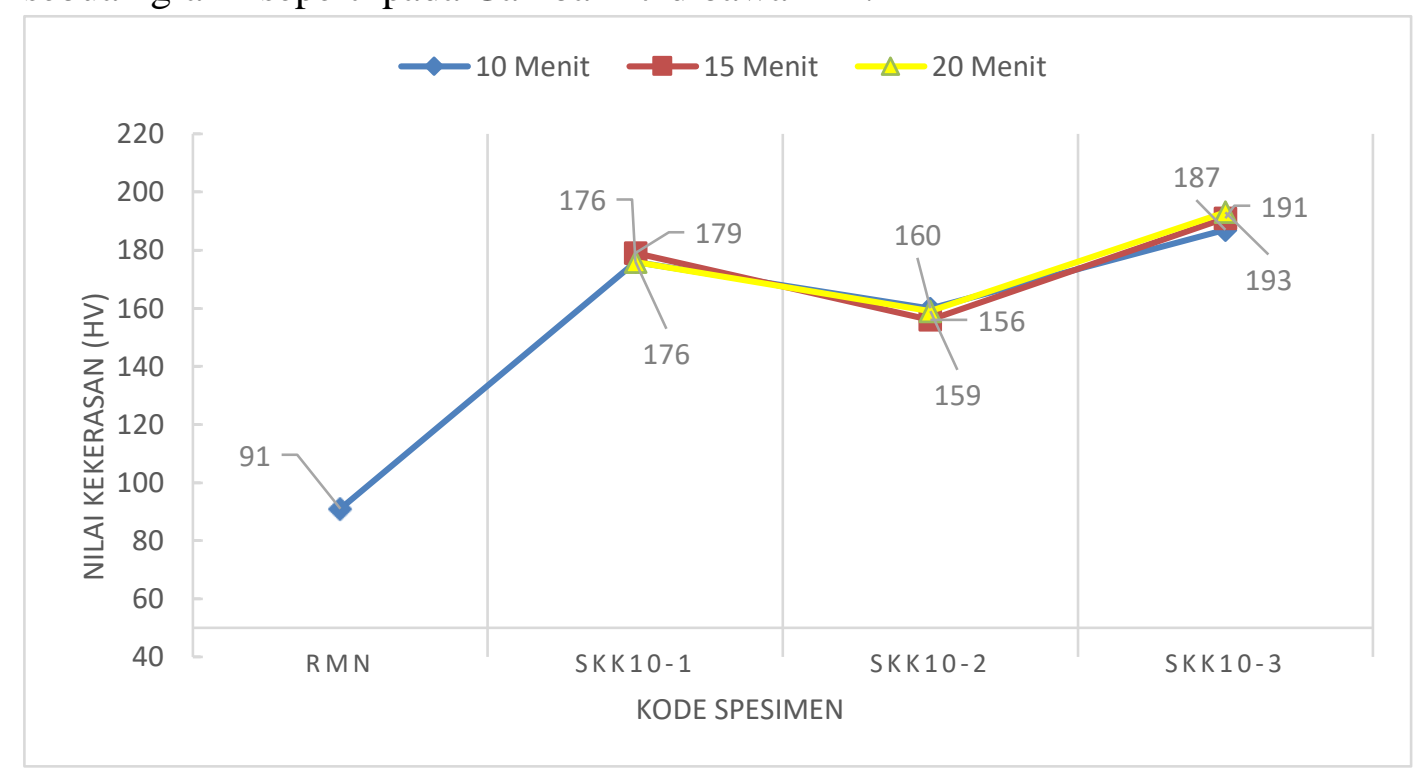

\section{Gambar 17 Grafik hasil pengujian kekerasan pelapisan nikel krom dengan kuat arus 10A}

Data grafik tersebut menunjukkan bahwa semakin besar kuat arus yang diberikan maka semakin banyak ion dari anoda sebagai bahan pelapis yang tereduksi dan terbawa menempel di permukaan logam induk sebagai katoda. Sehingga spesimen memiliki nilai kekerasan yang semakin baik terutama bila dibandingkan dengan spesimen yang tidak dilapisi.

Tabel 5 Hasil Uji Hardness Vickers dengan kuat arus 15 Ampere

\begin{tabular}{lccccc}
\hline \multirow{2}{*}{$\begin{array}{l}\text { No } \\
\text { Rata - Rata (HV) }\end{array}$} & \multicolumn{4}{c}{ Nilai Kekerasan } & \multirow{2}{*}{ Hasil Pengujian } \\
\cline { 3 - 5 } & & 1 & 2 & 3 & \\
\cline { 3 - 5 } & 91,0 & 91,0 & 91,0 & \\
\hline 1 & RM & 91 & & & \\
2 & SKK15-1 & 151 & 153 & 151 & 151 \\
3 & SKK15-2 & 156 & 156 & 159 & 157 \\
4 & SKK15-3 & 181 & 181 & 179 & 180 \\
\hline
\end{tabular}


Keterangan : $\mathrm{RM}=$ Raw Material

SKK15-1 = Sample Nikel Krom Kekerasan kuat arus 15 Ampere - titik ke 1

SKK15-2 = Sample Nikel Krom Kekerasan kuat arus 15 Ampere - titik ke 2

SKK15-3 = Sample Nikel Krom Kekerasan kuat arus 15 Ampere - titik ke 3

Hasil pengujian kekerasan pada Tabel 5 menghasilkan nilai kekerasan pada sample nikel krom kekerasan dengan arus 15 Ampere ke-1 mendapatkan nilai kekerasan sebesar $151 \mathrm{HV}$, kemudian nilai kekerasan pada sample nikel krom kekerasan dengan arus 15 Ampere ke-2 mendapatkan nilai kekerasan sebesar 157 HV dan selanjutnya pada nilai kekerasan sample nikel krom kekerasan dengan arus 15 Ampere mendapatkan nilai kekerasan sebesar $180 \mathrm{HV}$. Dari hasil pengujian kekerasan tsb dapat digambarkan dalam sebuah grafik seperti pada Gambar 18 dibawah ini.

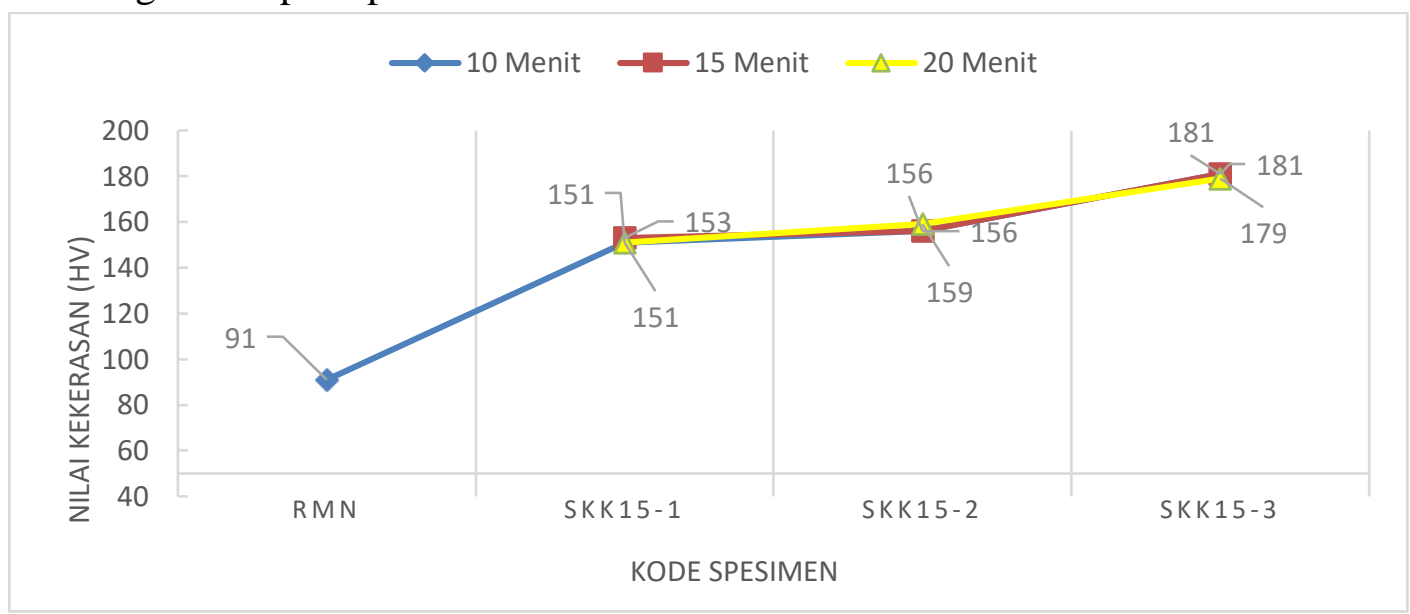

Gambar 18 Grafik hasil pengujian kekerasan pelapisan krom dengan kuat arus 15 A

Untuk sampel yang telah di electroplating dengan kuat arus 15 Ampere mempunyai nilai kekerasan $151 \mathrm{HV}$, meningkat dari nilai kekerasan raw material. Untuk sampel yang telah di electroplating dengan kuat arus 10 Ampere mempunyai nilai kekerasan $177 \mathrm{HV}$, meningkat dari nilai kekerasan raw material dan lebih tinggi dari nilai kekerasan kuat arus $10 \mathrm{~A}$ ampere.

Data tersebut menunjukkan bahwa semakin besar kuat arus yang diberikan maka semakin dikit ion dari anoda sebagai bahan pelapis yang tereduksi dan terbawa menempel di permukaan logam induk sebagai katoda. Sehingga spesimen memiliki nilai kekerasan yang semakin baik terutama bila dibandingkan dengan spesimen yang tidak dilapisi.

Tabel 6 Rata-rata hasil pengujian kekerasan

$\begin{array}{lrr}\text { Jenis Larutan } & & \text { Rata }- \text { Rata }\left(\mathrm{HV}_{\mathrm{B}}\right) \\ \text { Raw Material } & \text { RM } & 90,3 \\ \text { Nickel } & & \end{array}$




$\begin{array}{lll}\text { Kuat arus 10A } & \text { SNK10 } & 190,3 \\ \begin{array}{l}\text { Kuat arus 15A } \\ \text { Chrom }\end{array} & \text { SNK15 } & 198,3 \\ \text { Kuat arus 10A } & \text { SKK10 } & 175 \\ \text { Kuat arus 15A } & \text { SKK15 } & 162,6\end{array}$

Keterangan : RM = Raw Material

SNK10 $=$ Sample Nikel Kekerasan kuat arus 10 Ampere

SNK15 = Sample Nikel Kekerasan kuat arus 15 Ampere

SKK10 = Sample Nikel Krom Kekerasan kuat arus 10 Ampere

SKK15 = Sample Nikel Krom Kekerasan kuat arus 15 Ampere

Hasil pengujian kekerasan pada Tabel 6 menghasilkan rata-rata nilai kekerasan pada sample nikel dan nikel krom. Pada nilai kekerasan nikel dengan arus 10 Ampere mendapatkan rata-rata nilai kekerasan sebesar 190,3 HV, kemudian rata-rata nilai kekerasan pada sample nikel dengan arus 15 Ampere mendapatkan nilai kekerasan sebesar 198,3 HV. Sedangkan pada rata-rata nilai kekerasan sample nikel krom dengan arus 10 Ampere mendapatkan nilai kekerasan sebesar $175 \mathrm{HV}$ dan rata-rata nilai kekerasan sample nikel krom sebesar 162,6 HV. Dari rata-rata hasil pengujian kekerasan tsb dapat digambarkan dalam sebuah grafik seperti pada Gambar 19 dibawah ini.

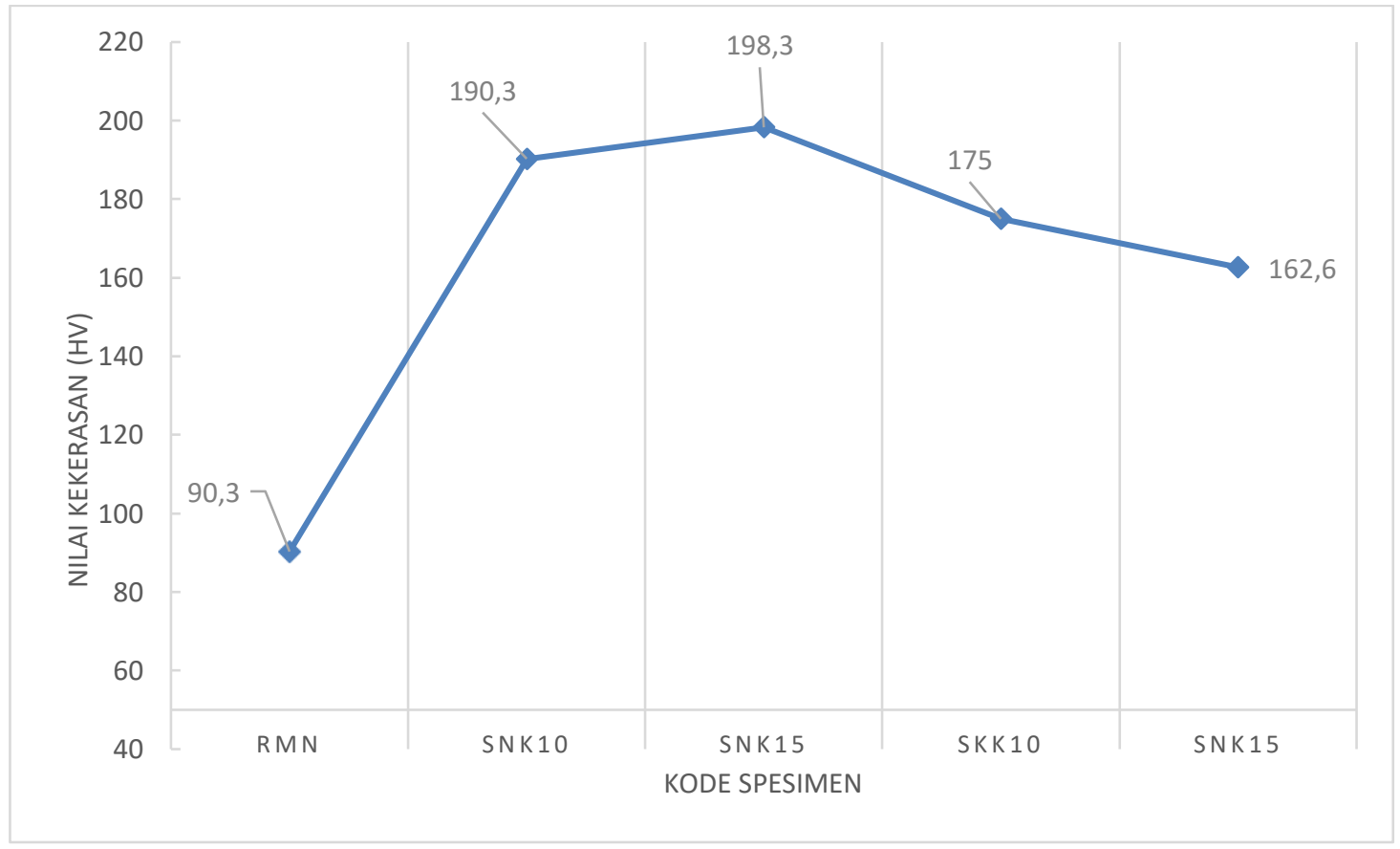

\section{Grafik 19 hasil pengujian kekerasan pelapisan nikel dan pelapisan krom dengan kuat arus $10 \mathrm{~A}$ dan $15 \mathrm{~A}$}

Data tersebut menunjukkan bahwa kuat arus dan bahan pelapis mempengaruhi banyaknya yang tereduksi dan terbawa menempel di permukaan logam sebagai katoda. 
Semakin besar kuat arus yang diberikan maka hasil kekerasannya pun akan mengalami hasil yang berbeda sesuai dengan pelapisnya. Semakin banyak ion dari anoda sebagai bahan pelapis yang tereduksi dan terbawa menempel di permukaan logam induk sebagai katoda. Sehingga spesimen memiliki nilai kekerasan yang semakin baik bila dibandingkan dengan spesimen yang dilapisi dengan 2 bahan pelapis.

4. Hasil dari Pengujian Ketebalan Lapisan dengan Mikroskopik

Hasil dari spesimen dengan pembesaran 100 kali dan 200 kali menggunakan etsa 2\% nital menghasilkan Ferite Perlite. Perbesaran dilakukan di 3 titik berbeda untuk mengetahui berapa ketebalan lapisan pada spesimen.

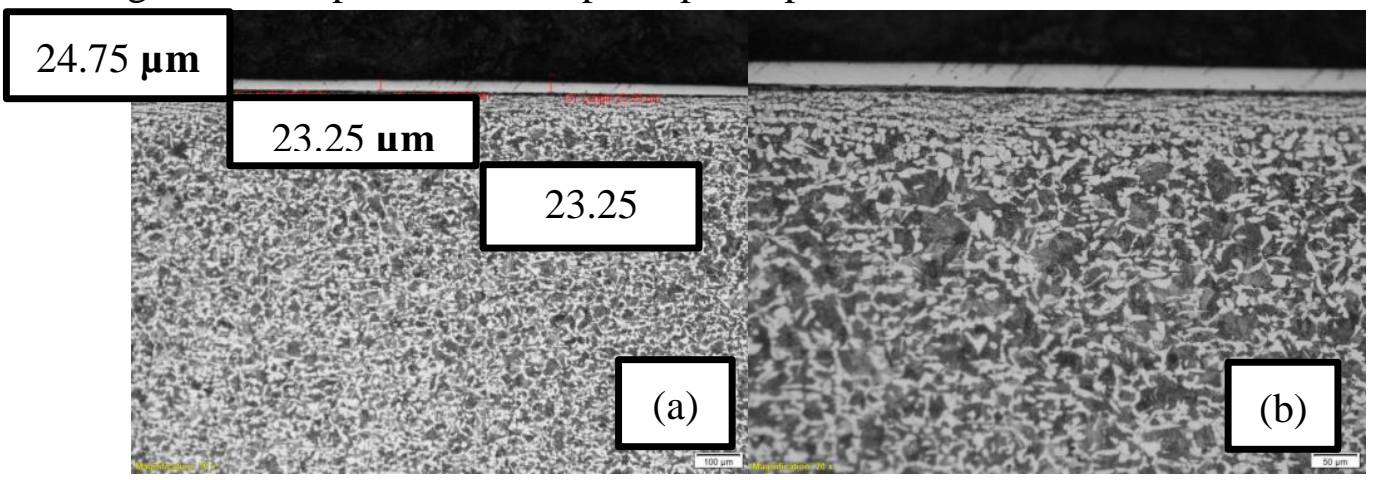

Gambar 20 (a) Hasil pembesaran 100 kali dari sample pelapisan nikel dengan arus 15A waktu 20 menit. (b) Hasil pembesaran 200 kali dari sample pelapisan nikel dengan arus $15 \mathrm{~A}$ waktu 20 menit

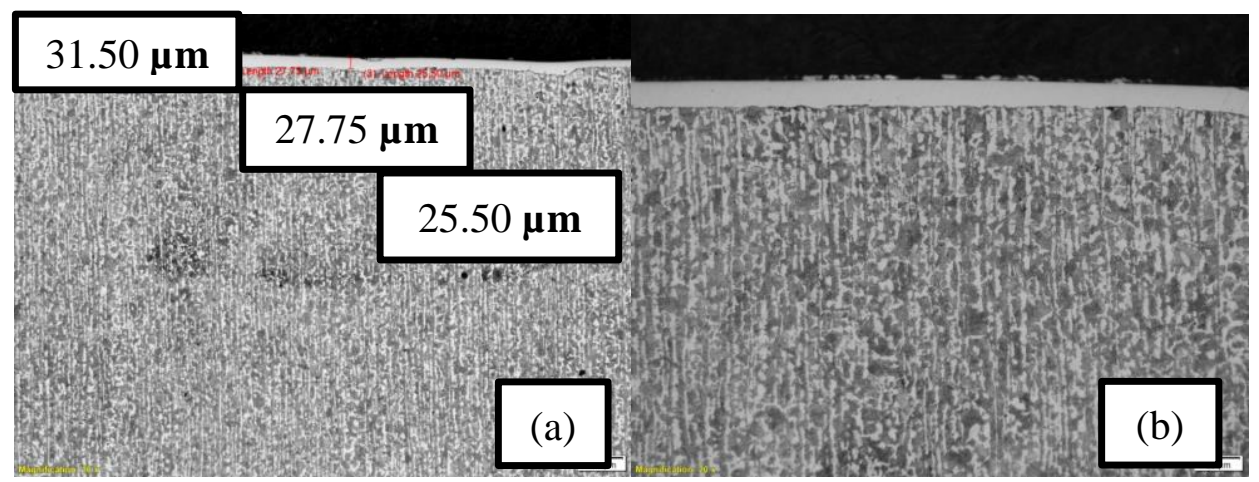

Gambar 21 (a) Hasil pembesaran 100 kali dari sample pelapisan nikel dengan arus 15A waktu 20 menit . (b) Hasil pembesaran 200 kali dari sample pelapisan krom dengan arus $15 \mathrm{~A}$ waktu 20 menit

Diatas merupakan foto mikro dengan perbesaran 100X dan 200X pada Gambar 20 menunjukan foto mikro dari spesimen pelapis nikel, terlihat nikel melapisi permukaan baja namun kurang optimal dan tebal lapisan hanya $23.25 \mu \mathrm{m}-24.75 \mu \mathrm{m}$, struktur mikro dari spesimen tersebut tetap ferit dan perlit. Selanjutnya pada Gambar 21 merupakan foto mikro dari spesimen pelapis krom mengalami peningkatan ketebalan lapisan $25.50 \mu \mathrm{m}-$ $31.50 \mu \mathrm{m}$ dan krom menutupi seluruh lapisan baja dengan optimal ini disebabkan oleh 
lebih besarnya kandungan logam pada unsur $\mathrm{NiCl} 2$ membuat kuat arus yang mengalir didalam larutan lebih besar sehingga ion-ion yang menempel dari anoda ke katoda semakin cepat, struktur mikro pada spesimen tidak ada perubahan tetap ferit dan perlit.

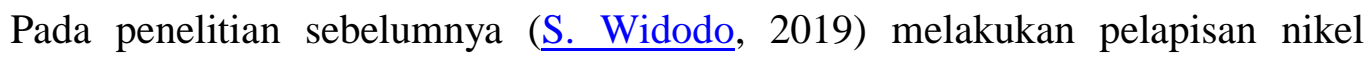
menggunakan metode electroplating dan jenis larutan sulfat klorida untuk mengetahui sifat mekanik dilakukanlah uji mikroskopis dengan hasil sebelum dan sesudah pelapisan tidak ada perubahan dalam strukur mikro material masih didominasi matrik ferit dan perlit. Baja kandungan karbon $0.025 \% \mathrm{~s} / \mathrm{d} 0.8 \%$ mengandung beragam jumlah ferit dan perlit serta porsinya tergantung pada kandungan karbon, transformasi baja karbon lebih kecil dari $0.025 \% \mathrm{C}$, alloy ini mulai transformasikan ke $\alpha$ pada $\mathrm{Fe}_{3} \mathrm{C}$ yang kecil mikro struktur dominan. Pada pendinginan eutectoid di titik S suhu $723^{\circ} \mathrm{C}$ semua austenit akan berubah menjadi $100 \%$ perlit, oleh karena itu struktur mikro pada suhu ruangan akan menunjukan lapisan-lapisan yang berubah dari ferit dan simentid disebut perlit $[31,32]$.

Dalam hal ini pemilihan jenis larutan tidak berpengaruh pada struktur mikro dari baja tersebut, ini dikarenakan baja dengan kandungan karbon $0.025 \%$ s/ $0.8 \%$ yang tersusun dari ferit dan pearlit hanya akan berubah struktur mikronya apabila dengan suhu proses lebih dari $723{ }^{\circ} \mathrm{C}$. Namun dari nilai ketebalan lapisan, larutan sulfat klorida merupakan larutan yang mampu membuat lapisan paling tebal dari pada larutan lainya, disusul larutan jenis all klorida, kemudian larutan jenis all sulfat. Ini akibatkan oleh kandungan logam nikel dan krom dari setiap larutan yang berbeda-beda sehingga mempengaruhi kuat arus yang mengalir didalam larutan elektrolit.

\section{Hasil dari Pengujian Scanning Electron Microscope (SEM)}

Pada pembahasan kali ini, akan ditampilkan hasil sample sebelumnya sudah dilapisi Ni dan Cr yang sudah mengalami pengujian Scanning Electron Microscope (SEM). Dalam pengujian Scanning Electron Microscope (SEM) ini, sample yang digunakan ada 2 jenis yaitu sample yang dilapisi nikel dan sample yang dilapisi nikel krom. Sample yang digunakan yaitu sample yang dilapisi Nikel dengan kuat arus 10A waktu 10 menit dan sample dengan kuat arus $10 \mathrm{~A}$ waktu 15 menit sedangkan sample yang dilapisi Krom dengan kuat arus 10A waktu 15 menit dan kuat arus 15A waktu 10 menit dengan masing-masing sample mengalami perbesaran 100x, 500x, 1000x dan 5000x.

a. Data Hasil dari Sample Pelapisan Nikel

Hasil dari spesimen dengan arus 10A waktu 10 menit dengan perbesaran 100x, 500x, 1000x dan 5000x. 


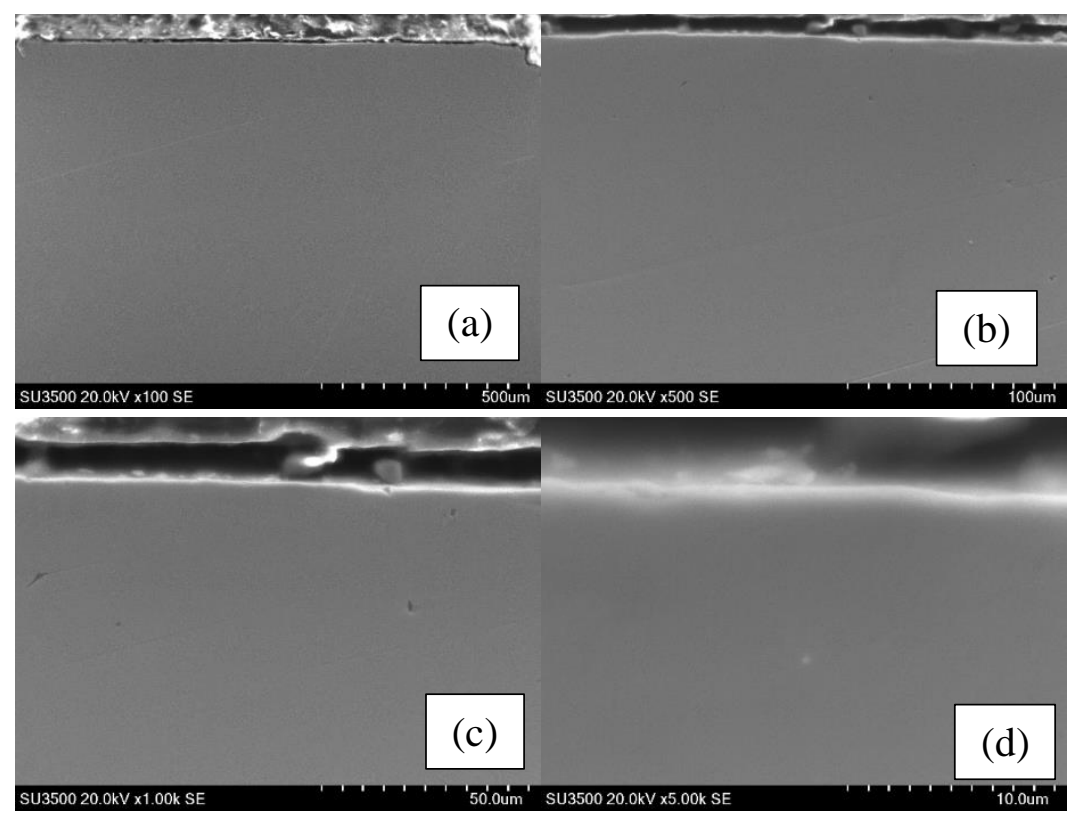

\section{Gambar 22 (a) Hasil perbesaran 100 kali. (b) Hasil perbesaran 500 kali. (c) Hasil perbesaran 1000x. (d) Hasil perbesaran 5000x dengan arus 10A waktu 10 menit}

Pada Gambar 22 ditampilkan foto SEM tampang permukaan lapisan Ni pada sampel pelapisan nikel dengan perbesaran 100 kali, 500 kali, 1000 kali dan 5000 kali. Gambar 22 (a) untuk sampel perbesaran 100 kali, Gambar 22 (b) untuk sample perbesaran 500 kali, Gambar 22 (c) untuk sample perbesaran 1000 kali, sedangkan Gambar 22 (d) untuk sample perbesaran 5000 kali dengan kuat arus 10A waktu 10 menit. Peneliti menganggap bahwa dengan menampilkan 4 foto permukaan lapisan nikel hasil elektroplating pada sample dengan kuat arus 10A waktu 10 menit dapat membandingkan hasil foto dengan perbesaran $100 \mathrm{kali}, 500 \mathrm{kali}, 1000$ kali dengan 5000 kali.

Pada hasil 4 kali perbesaran ini perbedaan tampilan permukaan lapisan nikel cukup mencolok, sample dengan hasil lapisan nikel dengan kuat arus 10A selama 10 menit mendapatkan tampilan permukaan lapisan nikel yang kurang jelas.

Pada Gambar 22 (a) butiran-butiran Ni pada permukaan lapisan nikel kurang tampak. Hal ini disebabkan karena dalam waktu tersebut kadar atom-atom Ni yang terdeposisi pada sample baja belum begitu banyak sehingga tampak permukaan dengan lapisan yang sangat tipis. Saat dilakukan untuk perbesaran lagi, tampak pada Gambar 22 (b) dan (c) tidak terlihat butiran-butiran di permukaan sample. Lain dengan Gambar 22 (d), hasil dari perbesaran yang lebih besar lagi menghasilkan gambar kurang jelas.

Hasil dari spesimen dengan arus 10A waktu 15 menit dengan perbesaran 100x, 500x, 1000x dan 5000x. 


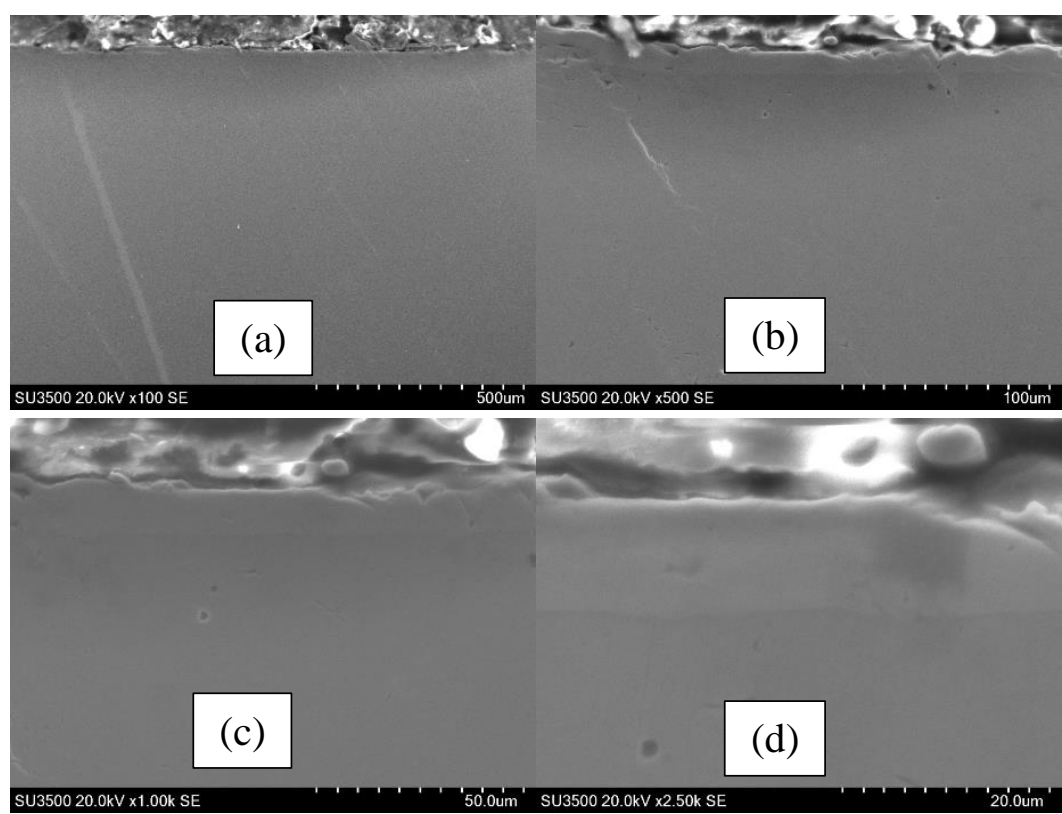

Gambar 23 Hasil perbesaran 100 kali. (b) Hasil perbesaran 500 kali. (c) Hasil perbesaran 1000x. (d) Hasil perbesaran 5000x dengan arus 10A waktu 15 menit

Selanjutnya hasil dari sample yang dilapisi nikel dengan arus 10A waktu 15 menit pada Gambar 23 (a), (b), (c) dan Gambar 23 (d) ditampilkan foto SEM tampang lintang sampel yang merupakan hasil deposisi Ni pada substrat $\mathrm{Cu}$ dalam waktu 15 menit dengan perbesaran 100 kali, 500 kali, 1000 kali dan 5000 kali. Dari hasil SEM ini ke-4 gambar tidak menampakkan adanya lapisan $\mathrm{Ni}$ pada $\mathrm{Cu}$, hal ini disebabkan lapisan $\mathrm{Ni}$ masih sangat tipis.

b. Data Hasil dari Sample Pelapisan Krom

Hasil dari spesimen dengan arus 10A waktu 15 menit dengan perbesaran 100x, 500x, 1000x dan 5000x.

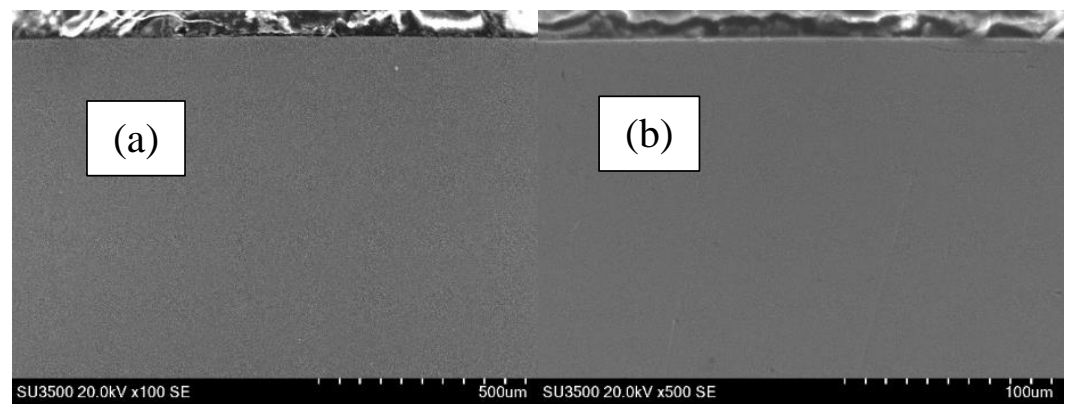




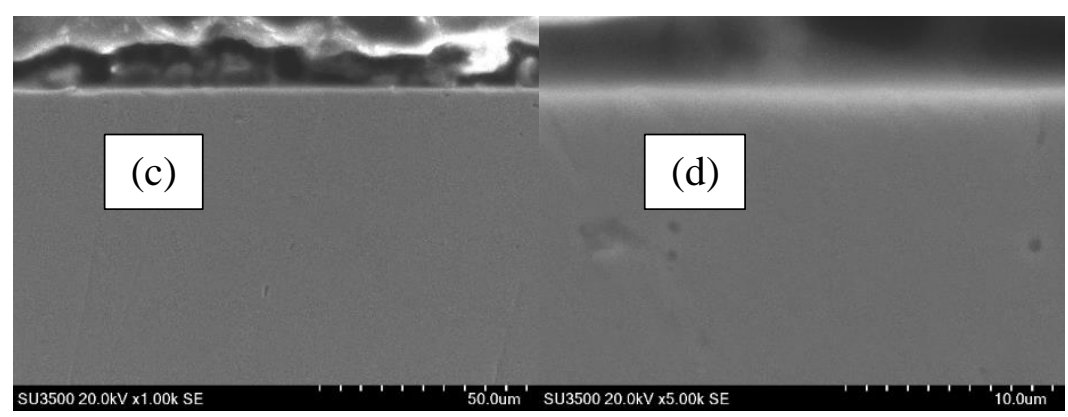

Gambar 24 (a) Hasil perbesaran 100 kali. (b) Hasil perbesaran 500 kali. (c) Hasil perbesaran 1000x. (d) Hasil perbesaran 5000x dengan arus 10A waktu 15 menit

Gambar 24 Foto SEM yang mendiskripsikan morfologi sampel pelapisan krom. (a) tampang permukaan lapisan $\mathrm{Cr}$ hasil perbesaran sebesar $100 \mathrm{kali}$, (b) tampang permukaan lapisan $\mathrm{Cr}$ hasil perbesaran sebesar $500 \mathrm{kali}$, (c) tampang lintang sampel $\mathrm{Cr}$ hasil perbesaran sebesar 1000 kali dan (d) tampang lintang sampel $\mathrm{Cr}$ hasil perbesaran sebesar 5000 kali.

Pada proses SEM ini menggunakan sample pelapisan krom dengan kuat arus 10A waktu 15 menit. Dari hasil SEM ini pun perbesaran ke-4 gambar tidak menampakkan adanya butiran lapisan $\mathrm{Cr}$ pada $\mathrm{Cu}$, hal ini disebabkan lapisan $\mathrm{Cr}$ sangat tipis.

Hasil dari spesimen dengan arus 15A waktu 10 menit dengan Perbesaran 100x, 500x, 1000x dan 5000x.

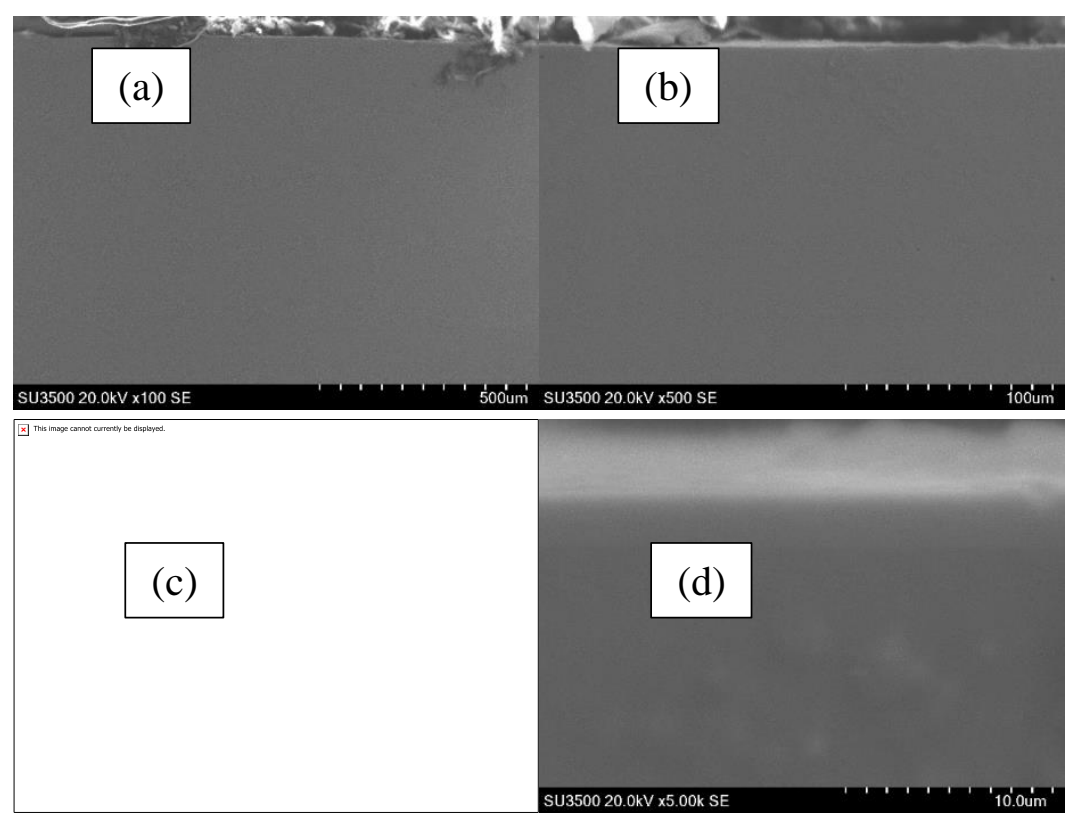

Gambar 25 (a) Hasil perbesaran 100 kali. (b) Hasil perbesaran 500 kali. (c) Hasil perbesaran 1000x. (d) Hasil perbesaran 5000x dengan arus 15A waktu 10 menit

Gambar 25 Foto SEM yang mendiskripsikan morfologi sampel pelapisan krom. (a) tampang permukaan lapisan $\mathrm{Cr}$ hasil perbesaran sebesar 100 kali, (b) tampang permukaan lapisan $\mathrm{Cr}$ hasil perbesaran sebesar $500 \mathrm{kali}$, (c) tampang lintang sampel $\mathrm{Cr}$ 
hasil perbesaran sebesar 1000 kali dan (d) tampang lintang sampel $\mathrm{Cr}$ hasil perbesaran sebesar 5000 kali.

Pada proses SEM ini menggunakan sample pelapisan krom dengan kuat arus 15A waktu 10 menit. Dari hasil SEM ini pun perbesaran ke-4 gambar tidak menampakkan adanya butiran lapisan $\mathrm{Cr}$ pada $\mathrm{Cu}$, yang didapatkan adalah tampilan perbesaran yang sangat tipis dari sample sebelumnya. Dengan membandingkan kedua sampel ini maka waktu deposisi berpengaruh pada pembentukan lapisan $\mathrm{Ni}$ dan $\mathrm{Cr}$ di permukaan $\mathrm{Cu}$. Semakin lama waktu deposisi semakin banyak lapisan $\mathrm{Ni}$ dan $\mathrm{Cr}$ yang menempel pada lapisan $\mathrm{Cu}$.

Pengujian Scanning Electron Microscope (SEM) Morfologi dilakukan untuk mengetahui morfologi dari permukaan lapisan nikel dan krom. Pengamatan dilakukan pada sample kuat arus 10A waktu 10 menit dan 10A waktu 15 menit untuk Pelapisan Nikel, sedangkan sample kuat arus 10A waktu 15 menit dan 15A waktu 10 menit untuk Pelapisan Krom. Pengamatan pada sample dilakukan dengan perbesaran 100x, 500x, 1000x dan 5000x pada masing-masing sample dengan variasi arusnya yang telah disebutkan.

Setelah diamati Pelapisan Nikel mempunyai ketebalan pada variasi kuat arus 10A waktu 15 menit tampak lebih tebal lapisan rata-rata 8,25 $\mu \mathrm{m}$. Sedangkan ketebalan lapisan pada variasi kuat arus 10A waktu 15 menit memiliki ketebalan lebih tipis yaitu 6,0 $\mu \mathrm{m}$. Dan Pelapisan Krom mempunyai ketebalan pada variasi kuat arus 10A waktu 15 menit tampak lebih tebal lapisan rata-rata $12,0 \mu \mathrm{m}$. Sedangkan ketebalan lapisan pada variasi kuat arus 15A waktu 10 menit memiliki ketebalan lebih tipis yaitu 5,25 $\mu \mathrm{m}$.

Pada penelitian sebelumnya oleh (TOIFUR \& SUKARELAWAN, 2017) pada sampel lapisan $\mathrm{Ni}$ dan $\mathrm{Cr}$ dapat menempel dengan kuat pada permukaan $\mathrm{Cu}$ karena terjadinya difusi atom $\mathrm{Ni}$ ke atom-atom $\mathrm{Cu}$. Hal ini sangat mungkin terjadi karena sebagaimana dikemukakan oleh Schleich bahwa secara atomik $\mathrm{Cu}$ dan Ni memiliki radius dan parameter kisi yang hampir sama dan memiliki struktur kristal sama yaitu fcc (face centered cubic). Selain itu gaya adesi pada interface antara $\mathrm{Cu}$ dan $\mathrm{Ni}$ yang cukup kuat juga membantu terbentuknya ikatan $\mathrm{Ni}$ ke permukaan $\mathrm{Cu}$ ini.

\section{Kesimpulan}

Dari hasil penelitian, dapat diperoleh beberapa kesimpulan sebagai berikut:

1. Pada Uji Laju Korosi, Pelapisan Nikel arus 10A dan 15A didapat nilai tahan korosi spesimen paling tertinggi pada arus 10A waktu 10 menit yaitu 0,000078 $\mathrm{Gram} / \mathrm{cm}^{2}$ dan nilai tahan korosi yang paling terendah adalah arus $15 \mathrm{~A}$ waktu 20 menit yaitu 0,000025 Gram $/ \mathrm{cm}^{2}$. Sedangkan Pelapisan Krom arus 10A dan 15A didapat nilai tahan korosi spesimen paling tertinggi pada arus 10A waktu 10 menit yaitu $0,000020 \mathrm{Gram} / \mathrm{cm}^{2}$ dan nilai tahan korosi yang paling terendah pada arus $15 \mathrm{~A}$ waktu 20 menit yaitu sebesar $0,00005 \mathrm{Gram} / \mathrm{cm}^{2}$.

2. Pada Uji Kekerasan pada Pelapisan Nikel arus 10A dan 15A didapat nilai kekerasan paling tertinggi pada arus 10A waktu 10 menit dengan nilai yaitu 217 HV dan nilai kekerasan terendah adalah arus 10A waktu 15 menit yaitu 
Pelapisan Baja Karbon Jis S50c Menggunakan Metode Elektroplating: Variasi Pelapisan Nickel (NI) dan Chrom (CR) Terhadap Sifat Fisik dan Sifat Kimia

148 HV. Sedangkan Uji Kekerasan pada Pelapisan Krom arus 10A dan 15A didapat nilai kekerasan paling tertinggi pada arus 15A waktu 20 menit dengan nilai yaitu $541 \mathrm{HV}$ dan nilai kekerasan terendah adalah arus $15 \mathrm{~A}$ waktu 10 menit yaitu $151 \mathrm{HV}$.

3. Uji Ketebalan Lapisan dengan Mikroskopik, pada Pelapisan Nikel arus 10A dan 15A didapat nilai ketebalan spesimen paling tertinggi pada arus $15 \mathrm{~A}$ waktu 20 menit yaitu 23,75 $\boldsymbol{\mu m}$ dan nilai ketebalan terendah adalah arus $15 \mathrm{~A}$ waktu 15 menit yaitu 6,5 $\mu \mathrm{m}$. Sedangkan pada Pelapisan Krom arus 10A dan 15A didapat nilai ketebalan spesimen paling tertinggi pada arus $15 \mathrm{~A}$ waktu 20 menit yaitu 28,0 $\mu \mathrm{m}$ dan nilai ketebalann terendah adalah arus $10 \mathrm{~A}$ waktu 10 menit yaitu $6,0 \mu \mathrm{m}$.

4. Pada Uji SEM, Setelah diamati Pelapisan Nikel mempunyai ketebalan pada variasi kuat arus $10 \mathrm{~A}$ waktu 15 menit tampak lebih tebal lapisan rata-rata 8,25 $\mu \mathrm{m}$. Sedangkan ketebalan lapisan pada variasi kuat arus 10A waktu 15 menit memiliki ketebalan lebih tipis yaitu 6,0 $\mu \mathrm{m}$. Dan Pelapisan Krom mempunyai ketebalan pada variasi kuat arus 10A waktu 15 menit tampak lebih tebal lapisan rata-rata $12,0 \mu \mathrm{m}$. Sedangkan ketebalan lapisan pada variasi kuat arus 15A waktu 10 menit memiliki ketebalan lebih tipis yaitu 5,25 $\mu \mathrm{m}$. 


\section{Bibbliography}

Bimariga, K. (2018). Pengaruh Variasi Kuat Arus Terhadap Ketebalan, Kekerasan dan Ketahanan Korosi Hasil Elektroplating Nikel-Hard Chromium pada Baja AISI 4340. Institut Teknologi Sepuluh Nopember.

Hamzah, M. S., \& Iqbal, M. (2008). Peningkatan ketahanan aus baja karbon rendah dengan metode carburizing. SMARTek, 6(3).

Jauhari, P. (2017). PENGARUH VARIASI TEGANGAN DAN WAKTU PADA PROSES PELAPISAN NIKEL TERHADAP KEKUATAN BENDING BAJA ST 41. Jurnal Teknik Mesin, 5(01).

Pratama, S. D., \& Sakti, A. M. (2018). Analisis Pelapisan Nikel-Krom Terhadap Laju Korosi Pada Knalpot Sepeda Motor. Jurnal Pendidikan Teknik Mesin, 6(03).

Putra, F. S. A. (2012). Pengaruh arus dan waktu pelapisan hard chrome terhadap ketebalan lapisan dan kekerasan pada plat baja karbon rendah aisi 1026 dengan elektroplating menggunakan hcro3 $250 \mathrm{gr} / \mathrm{lt}$ dan h2so4 1, $25 \mathrm{gr} / \mathrm{lt}$.

Sandi, A. P., Suka, E. G., \& Supriyatna, Y. I. (2017). Pengaruh Waktu Elektroplating Terhadap Laju Korosi Baja AISI 1020 Dalam Medium Korosif NaCl 3\%. Jurnal Teori Dan Aplikasi Fisika, 5(2), 205-212.

Susanto, A. (2016). Analisis kepadatan pada proses pelapisan nikel krom dengan variasi kuat arus dan lama pencelupan baja st 42. Jurnal Teknik Mesin, 4(03).

TOIFUR, M. O. H., \& SUKARELAWAN, I. (2017). PENGARUH WAKTU DEPOSISI PADA TEBAL LAPISAN, STRUKTUR MIKRO, RESISTIVITAS KEPING LAPISAN TIPIS CU/NI HASIL DEPOSISI DENGAN TEKNIK ELEKTROPLATING. Jurnal Material Dan Energi Indonesia, 7(02), 33-43.

Widodo, B., \& Asmoro, W. P. (2012). Analisa Chrome Deposit dan Hardness pada Proses Hard Chrome dengan Variasi Arus untuk Roda Gigi Sepeda Motor. Jurnal Teknologi Technoscientia, 4(2), 120-127.

Widodo, S. (2019). PENGARUH ENERGI AKTIVASI LOGAM PELAPIS TERHADAP KETEBALAN DAN LAJU KOROSI PLATING. Journal of Mechanical Engineering, 3(1), 8-14.

Yanto, D. D. (2018). PENGARUH ELEKTROPLATING NIKEL TERHADAP KETEBALAN LAPISAN, KEKASARAN, DAN KEKERASAN PERMUKAAN 
Pelapisan Baja Karbon Jis S50c Menggunakan Metode Elektroplating: Variasi Pelapisan Nickel (NI) dan Chrom (CR) Terhadap Sifat Fisik dan Sifat Kimia

TITANIUM DENGAN VARIASI WAKTU $20, \quad 40, \quad 60, \quad 80$ MENIT. Photosynthetica, 2(1), 1-13. 